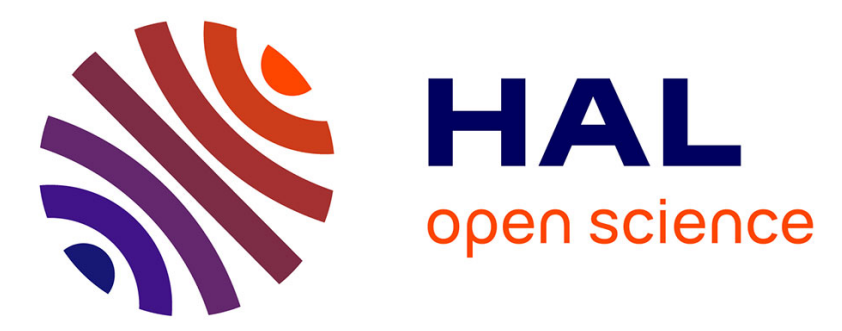

\title{
Source contributions to Northern Hemisphere CO and black carbon during spring and summer 2008 from POLARCAT and START08/preHIPPO observations and MOZART-4
}

S. Tilmes, L. K. Emmons, Kathy S. Law, Gérard Ancellet, H. Schlager, J.-D.

Paris, Henry E. Fuelberg, D. G. Streets, C. Wiedinmyer, G. S. Diskin, et al.

\section{To cite this version:}

S. Tilmes, L. K. Emmons, Kathy S. Law, Gérard Ancellet, H. Schlager, et al.. Source contributions to Northern Hemisphere CO and black carbon during spring and summer 2008 from POLARCAT and START08/preHIPPO observations and MOZART-4. 2015. hal-00568788

\author{
HAL Id: hal-00568788 \\ https://hal.science/hal-00568788
}

Preprint submitted on 22 Dec 2015

HAL is a multi-disciplinary open access archive for the deposit and dissemination of scientific research documents, whether they are published or not. The documents may come from teaching and research institutions in France or abroad, or from public or private research centers.
L'archive ouverte pluridisciplinaire HAL, est destinée au dépôt et à la diffusion de documents scientifiques de niveau recherche, publiés ou non, émanant des établissements d'enseignement et de recherche français ou étrangers, des laboratoires publics ou privés. 
Atmos. Chem. Phys. Discuss., 11, 5935-5983, 2011

www.atmos-chem-phys-discuss.net/11/5935/2011/

doi:10.5194/acpd-11-5935-2011

(C) Author(s) 2011. CC Attribution 3.0 License.

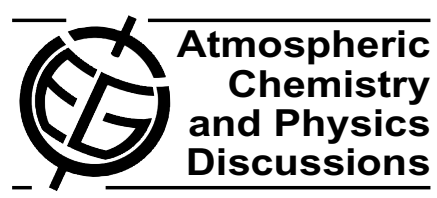

\section{ACPD}

$11,5935-5983,2011$

This discussion paper is/has been under review for the journal Atmospheric Chemistry and Physics (ACP). Please refer to the corresponding final paper in ACP if available.

\section{Source contributions to Northern}

Hemisphere $\mathrm{CO}$ and black carbon during spring and summer 2008 from POLARCAT and START08/preHIPPO observations and MOZART-4

S. Tilmes $^{1}$, L. K. Emmons ${ }^{1}$, K. S. Law ${ }^{2}$, G. Ancellet ${ }^{2}$, H. Schlager ${ }^{3}$, J.-D. Paris ${ }^{4}$, H. E. Fuelberg ${ }^{5}$, D. G. Streets ${ }^{6}$, C. Wiedinmyer ${ }^{1}$, G. S. Diskin ${ }^{7}$, Y. Kondo ${ }^{8}$, J. Holloway ${ }^{9,10}$, J. P. Schwarz ${ }^{9,10}$, J. R. Spackman ${ }^{9,10}$, T. Campos ${ }^{1}$, P. Nédélec ${ }^{11}$, and M. V. Panchenko ${ }^{12}$

\footnotetext{
${ }^{1}$ National Center for Atmospheric Research, Boulder, Colorado, USA

${ }^{2}$ LATMOS-IPSL; UPMC Univ. Paris 06; Univ. Versailles St-Quentin; CNRS/INSU, Paris, France

${ }^{3}$ Institute for Physics of the Atmosphere, Oberpfaffenhofen, Wessling, Germany

${ }^{4}$ Laboratoire des Sciences du Climat et de l'Environnement/IPSL, CNRS-CEA-UVSQ,

Orme des Merisiers, CEA Saclay, Gif sur Yvette, France

${ }^{5}$ Florida State University, USA
}

Source contributions to NH CO and black carbon during spring and summer 2008

S. Tilmes et al.

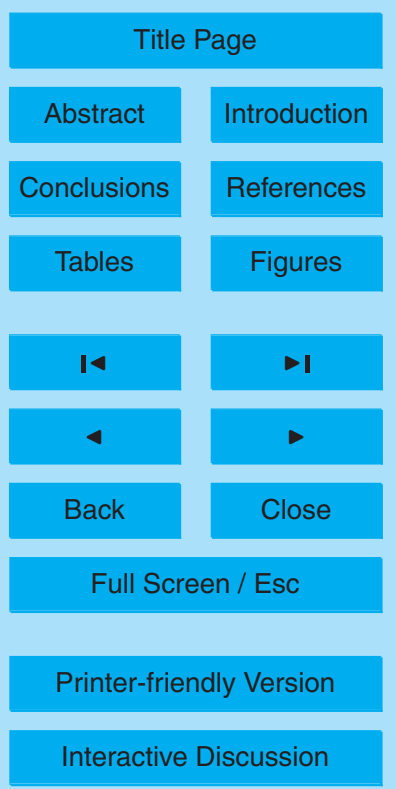


${ }^{6}$ Argonne National Laboratory, DIS/221 9700 South Cass Avenue Argonne, Illinois 60439, USA

${ }^{7}$ NASA Langley Research Center, Hampton, Virginia, USA

${ }^{8}$ Research Center for Advanced Science and Technology, The University of Tokyo 4-6-1 Komaba, Meguro, Tokyo 153-8904, Japan

${ }^{9}$ NOAA Earth System Research Laboratory, Boulder, CO, USA

${ }^{10}$ Cooperative Institute for Research in Environmental Sciences (CIRES), University of Colorado, Boulder, USA

${ }^{11}$ Laboratoire d'Aérologie, CNRS-UPS, Toulouse, France

${ }^{12}$ Institute of Atmospheric Optics, SB-RAS, Tomsk, Russia

Received: 24 January 2011 - Accepted: 7 February 2011 - Published: 21 February 2011

Correspondence to: S. Tilmes (tilmes@ucar.edu)

Published by Copernicus Publications on behalf of the European Geosciences Union.

\section{ACPD}

$11,5935-5983,2011$

\section{Source contributions to NH CO and black carbon during spring and summer 2008}

S. Tilmes et al.

Title Page

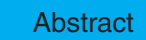

Introduction

Conclusions

References

Tables

Figures

14

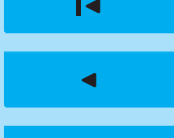

$\rightarrow 1$

Back

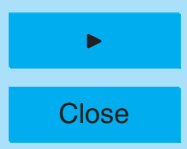

Full Screen / Esc

Printer-friendly Version

Interactive Discussion 


\section{Abstract}

Anthropogenic pollution and wildfires are main producers of carbon monoxide (CO) and black carbon $(\mathrm{BC})$ in the Northern Hemisphere. High concentrations of these compounds are transported into the Arctic troposphere, influencing the ecosystem in 5 high northern latitudes and the global climate. The global chemical transport model MOZART-4 is used to quantify the seasonal evolution of the contribution of $\mathrm{CO}$ and $\mathrm{BC}$ from different source regions in spring and summer 2008 by tagging their emissions. Aircraft observations from the POLARCAT experiments, in particular NASA ARCTAS, NOAA ARCPAC, POLARCAT-France, DLR GRACE and YAK-AEROSIB, as well as the 10 NSF START08/preHIPPO experiments during Spring-Summer 2008 are combined to quantify the representation of simulated tracer characteristics in anthropogenic and fire plumes. In general, the model reproduces $\mathrm{CO}$ and $\mathrm{BC}$ well. Based on aircraft measurements and FLEXPART back-trajectories, the altitude contribution of emissions coming from different source regions is well captured in the model. Uncertainties of the

15 MOZART-4 model are identified by comparing the data with model results on the flight tracks and using MOPITT satellite observations. Anthropogenic emissions are underestimated by about $10 \%$ in high northern latitudes in spring, and shortcomings exist in simulating fire plumes. The remote impact of East-Siberian fire emissions is underestimated for spring, whereas the impact of Southeast Asian fire emissions to mid-latitude $\mathrm{CO}$ values is overestimated by the model. In summer, mid-latitude $\mathrm{CO}$ values agree well between model and observations, whereas summer high latitude East-Siberian fire emissions in the model are overestimated by $20 \%$ in comparison to observations in the region. On the other hand, $\mathrm{CO}$ concentrations are underestimated by about $30 \%$ over Alaska and Canada at altitudes above $4 \mathrm{~km}$. BC values are overestimated by the 25 model at altitudes above $4 \mathrm{~km}$ in summer. Based on MOZART-4, with tagged CO and $\mathrm{BC}$ tracers, anthropogenic emissions of Asia, Europe and the US have the largest contribution to the $\mathrm{CO}$ and $\mathrm{BC}$ in mid- and high latitudes in spring and summer. Southeast Asian, Chinese and Indian fires have a large impact on $\mathrm{CO}$ pollution in spring in low

\section{Source contributions to NH CO and black carbon during spring and summer 2008}

S. Tilmes et al.

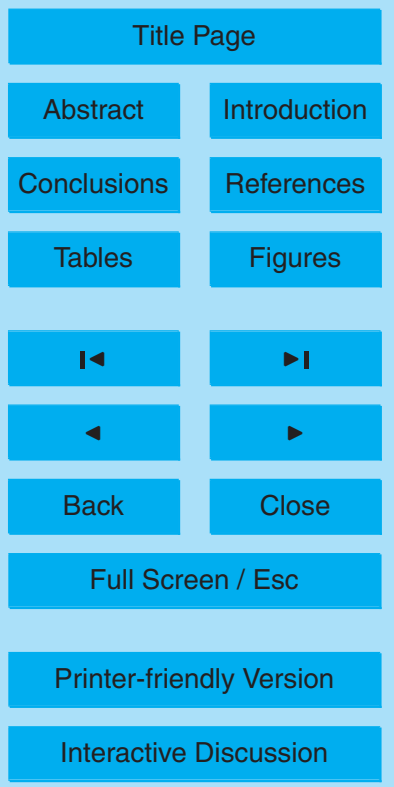


latitudes with a maximum between $20^{\circ}$ and $30^{\circ} \mathrm{N}$, whereas Siberian fires contribute largely to the pollution in high latitudes, up to $10 \%$ in spring and up to $30 \%$ in summer. The largest contributions to $\mathrm{BC}$ values in high latitudes are from anthropogenic emissions (about 70\%). CO and BC have larger mass loadings in April than in July, as a 5 result of photochemistry and dynamics.

\section{Introduction}

Anthropogenic pollution and wildfires are the main producers of carbon monoxide (CO) and black carbon (BC) in the Northern Hemisphere (NH). These tracers are transported from mid-latitudes into the Arctic troposphere, where they influence the ecosystems at 10 high northern latitudes. Tropospheric $\mathrm{CO}$ accumulates in winter and spring in high latitudes due to the reduced photochemistry as a result of little sunlight. Between spring and late summer, fires significantly contribute to the amount of $\mathrm{CO}$ and $\mathrm{BC}$ in the Arctic. $\mathrm{CO}$ is an important precursor for ozone and therefore has an influence on the tropospheric ozone budget and climate. Due to its strongly light-absorbing characteristic, $15 \mathrm{BC}$ has an important impact on the global radiation budget and climate (Clarke and Noone, 1985; Hansen and Nazarenko, 2004; Flanner et al., 2007; Koch and Del Genio, 2010) and contributes to the rapid warming of the Arctic (Christensen et al., 2007). The deposition of $B C$ on snow changes its albedo and leads to increased snow and icemelt (Flanner et al., 2009). A precise description of $\mathrm{CO}$ and $\mathrm{BC}$ in climate models is 20 important for simulating a realistic climate impact of pollution (Jacobson, 2001). Recent studies indicate large discrepancies in BC mass between models and observations in the Arctic troposphere (Koch et al., 2009; Shindell and Faluvegi, 2009). It is therefore crucial to understand the seasonal variation of $\mathrm{CO}$ and $\mathrm{BC}$ and estimate the contributions from source regions of pollution based on observations, as a basis for climate 25 model evaluation.

The international program Polar Study using Aircraft, Remote Sensing, Surface Measurements and Models, of Climate, Chemistry, Aerosols, and Transport (POLARCAT)

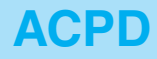

$11,5935-5983,2011$

\section{Source contributions to NH CO and black carbon during spring and summer 2008}

S. Tilmes et al.

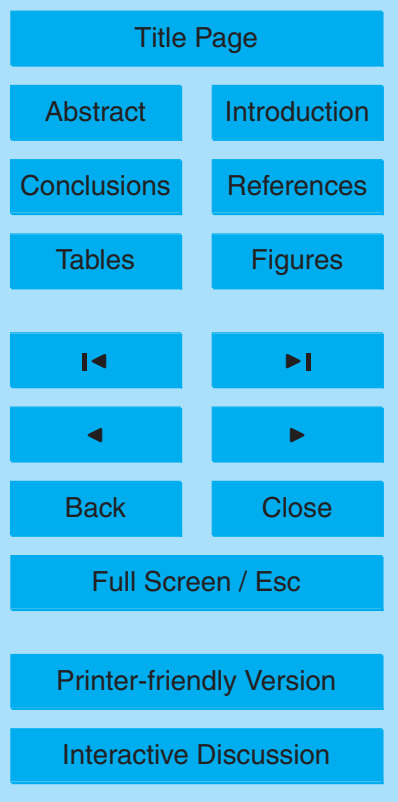


consisted of several concurrent field programs that were conducted in spring and summer 2008 during the International Polar Year 2007-2008 (http://www.polarcat.no/). POLARCAT aircraft campaigns in 2008 were designed to better understand the factors driving current changes in Arctic atmospheric composition and climate (Jacob et al., 5 2010; Brock et al., 2010). Consequently, POLARCAT aircraft campaigns sampled for the most part polluted airmasses and fire plumes in the high northern latitudes. The $C O$ and $\mathrm{BC}$ contributions from different source regions to individual aircraft campaigns and single seasons have been discussed (e.g. Warneke et al., 2009; Fisher et al., 2010; Paris et al., 2009; de Villiers et al., 2010). However, single aircraft campaigns might not 10 represent the airmass characteristics of the entire polar cap.

Here, we employ five POLARCAT aircraft campaigns that took place in spring and summer 2008, to quantify the $\mathrm{CO}$ and $\mathrm{BC}$ contribution of pollution by fires and anthropogenic emissions. These aircraft campaigns covered different regions of the Arctic and sampled the varying influence of pollution. In addition, we use observations from 15 the Stratosphere-Troposphere Analyses of Regional Transport (START08) and the test case of the HIAPER Pole-to-Pole Observation mission (preHIPPO) aircraft campaign. This campaign was designed to target exchange processes between Upper Troposphere and Lower Stratosphere (UTLS) (Pan et al., 2010). The latter took place for the most part in mid-latitudes over North America during the same period as the POLARCAT campaigns and did not target any pollution plumes in the troposphere. The extensions of these additional observations in lower latitudes complement results from high latitudes and give further insight into the $\mathrm{CO}$ contributions of anthropogenic and fire emissions in the entire $\mathrm{NH}$.

We study the $\mathrm{CO}$ and $\mathrm{BC}$ contribution of different source regions in spring and sum25 mer and for different periods and regions that are covered by aircraft data to get a good representation of the entire polar region. $\mathrm{CO}$ and $\mathrm{BC}$ are tracers that are well suited to study the transport of airmasses reaching high latitudes from different parts of the world, because the lifetime of $\mathrm{CO}$ is at least 1-2 months and several days for BC (e.g. Paris et al., 2009). We used the global chemical transport model MOZART-4 (Emmons

\section{ACPD}

$11,5935-5983,2011$

Source contributions to NH CO and black carbon during spring and summer 2008

S. Tilmes et al.

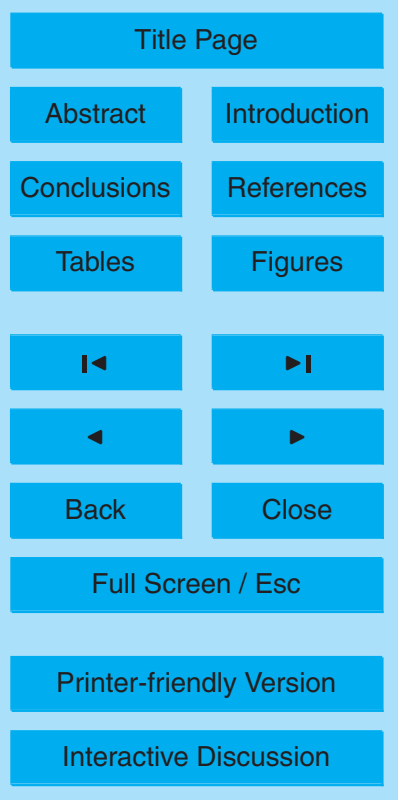


et al., 2010) to quantify the influence of fire and anthropogenic emissions by tagging $\mathrm{BC}$ and $\mathrm{CO}$ emissions for different regions. We further use FLEXPART trajectories (Fuelberg et al., 2010) to identify the source region of observed airmasses. To estimate the range of uncertainty of simulated $\mathrm{CO}$ and $\mathrm{BC}$, we compare the model results 5 that are spatially and temporally interpolated to the flight tracks of the aircraft data. In addition, we use retrievals of $\mathrm{CO}$ from the Measurements of Pollution In The Troposphere (MOPITT) instrument on the Terra satellite (e.g., Deeter et al., 2010) to identify shortcomings of $\mathrm{CO}$ in the source regions of pollution for different periods of the aircraft campaigns. Finally, we calculate the contribution of $\mathrm{CO}$ and $\mathrm{BC}$ source regions for the 10 entire $\mathrm{NH}$ and provide an overview of the seasonal and latitudinal varying importance of anthropogenic and fire emissions in the NH using MOZART-4.

\section{Aircraft campaigns April-July 2008 and MOPITT satellite data}

\subsection{Aircraft data}

The aircraft missions used in this study are listed in Table 1. Some missions are divided 15

\section{during the periods considered are shown in Fig. 1.}

into more than one time interval and cover different areas. The location of the flights

The NASA Arctic Research of the Composition of the Troposphere from Aircraft and Satellites (ARCTAS) mission (Jacob et al., 2010) was grouped into three parts, ARCTAS-A, ARCTAS-B and ARCTAS-CARB. Three research aircraft took part in this campaign with a slightly different target of each mission. Here, we use the $\mathrm{CO}$ and BC data from the NASA DC-8 to study the transport from mid-latitudes to the Arctic. ARCTAS-A and ARCTAS-B targeted mid-latitude pollution layers transported to the Arctic and wildfire plumes, respectively. ARCTAS-CARB was focused on California air quality targeting fresh fire plumes in northern California, as well as various 25 anthropogenic sources (Huang et al., 2010; Pfister et al., 2011). We concentrate on ARCTAS-A observations that were taken in high latitudes (above $60^{\circ} \mathrm{N}$ ) and therefore

\section{ACPD}

$11,5935-5983,2011$

Source contributions to NH CO and black carbon during spring and summer 2008

S. Tilmes et al.

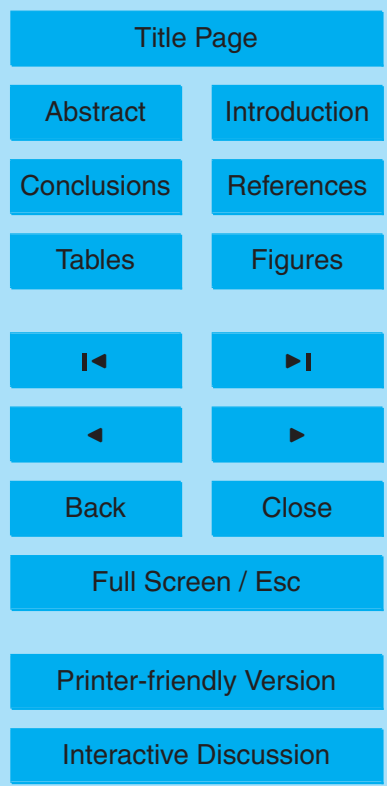


do not include the transit flights between California and Alaska. We further separate ARCTAS-A flights into two periods. The first period (Spring1) includes data that were for the most part not influenced by Siberian fire emissions, whereas the second part (Spring2) is strongly influenced by fire emissions. ARCTAS-B is also split into two 5 groups, one including flights that sample lower latitudes and a second including flights that sample higher latitudes (see Table 1).

The NOAA ARCPAC (Aerosol, Radiation, and Cloud Processes affecting Arctic Climate) mission was conducted in spring between the end of March and 21 April using the WP-3D aircraft. It was designed to understand the radiative impacts of anthro10 pogenic pollution and biomass burning sources. The campaign was based in Fairbanks and frequently targeted fire plumes that were transported from Siberia (e.g., Warneke et al., 2009; Brock et al., 2010). For ARCPAC we consider all flights starting on 11 April, which covered latitudes north of $63^{\circ} \mathrm{N}$.

The scientific objectives of POLARCAT-France and POLARCAT-GRACE (Greenland 15 Aerosol and Chemistry Experiment) are similar to those of the ARCTAS and ARCPAC missions. However, these aircraft missions took place in Europe and Greenland. POLARCAT-France, using the French ATR-42 aircraft, was based in Kiruna, Sweden, in Spring, and took place between 30 March and 11 April (de Villiers et al., 2010). The summer mission was based in western Greenland in Kangerlussuaq and took place between end of June and mid-July. The POLARCAT-GRACE mission was conducted during the same time (1-17 July), using the DLR Falcon research aircraft. BC was not measured during either campaign.

The YAK-AEROSIB (Airborne Extensive Regional Observations in Siberia) was conducted in July 2008 covering the area of North and Central Siberia and using an

25 Antonov-30 research aircraft, operated by the Tomsk Institute of Atmospheric Optics (Paris et al., 2008). This campaign was also performed in collaboration with the POLARCAT program (Paris et al., 2009). During the first part of the mission (7-12 July 2008), CO but no BC measurements are available, whereas during the second part (21-29 July) BC was observed in addition to $\mathrm{CO}$ and other species. During the second

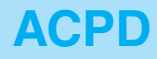

$11,5935-5983,2011$

Source contributions to $\mathrm{NH} \mathrm{CO}$ and black carbon during spring and summer 2008

S. Tilmes et al.

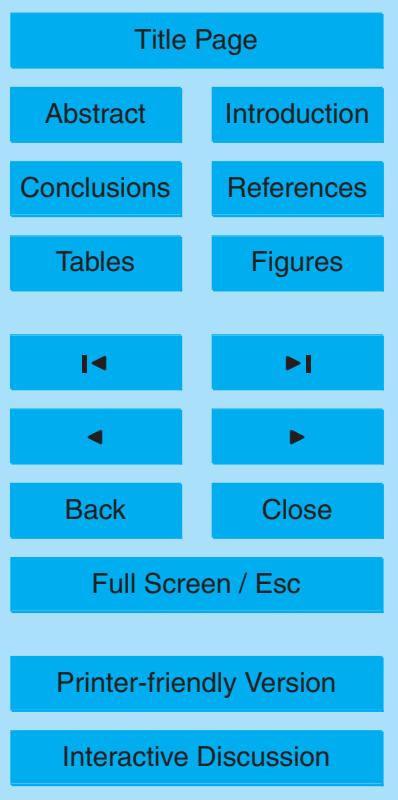

Interactive Discussion 
part of the mission, a number of biomass burning plumes over Siberia were encountered.

The NSF START08/preHIPPO aircraft campaign was conducted the same time as the POLARCAT mission in spring and summer 2008 (Pan et al., 2010). This cam5 paign was designed to target exchange processes between Upper Troposphere and Lower Stratosphere (UTLS). The preHIPPO mission shared the START08 payload and focused on testing global observations of greenhouse gases. A wingtip-to-wingtip comparison was made between the ARCTAS DC8 and NSF/NCAR Gulfstream V (GV) aircraft, showing agreement within the measurement uncertainties between the two CO measurements. BC was not measured during START08/preHIPPO.

A description of $C O$ measurements for the POLARCAT missions, ARCTAS, ARCPAC, POLARCAT-France, POLARCAT-GRACE and YAK-AEROSIB are given in Pommier et al. (2010). A brief description of CO measurements for the START08/Hippo campaign is given in Tilmes et al. (2010). Wingtip-to-wingtip comparisons were also 15 made between NASA-DC8 DACOM CO, the NOAA WP-3D and DLR Falcon Vacuum UV fluorescence CO measurements within the International Consortium for Atmospheric Research on Transport and Transformation ICARTT (2010). Further, intercomparisons between NSF-GV NCAR CO and the NASA-DC8 DACOM CO were performed, as well as between the DLR Falcon and the ATR-42 on 14 July 2008, above Greenland (Kleb et al., 2009). The CO measurements agree for different campaigns within their range of uncertainty (between 2-5\%).

$B C$ was measured during ARCTAS on the NASA DC8, during ARCPAC on the NOAA P3 and during YAK-AEROSIB on the Antonov-30 aircraft. For both ARCTAS and ARCPAC campaigns a Single Particle Soot Photometer (SP2) was used, which has been described elsewhere (Spackman et al., 2010; Schwarz et al., 2010; Moteki and Kondo, 2010; Kondo et al., 2010). Briefly, the SP2 uses an intense intracavity laser to heat the refractory carbon component of fine-mode aerosols to vaporization. Analysis of the thermal radiation emitted by the particle is used to determine the mass of the refractory component and to constrain its carbon composition. The instrument operated on the

\section{Source contributions} to NH CO and black carbon during spring and summer 2008

S. Tilmes et al.

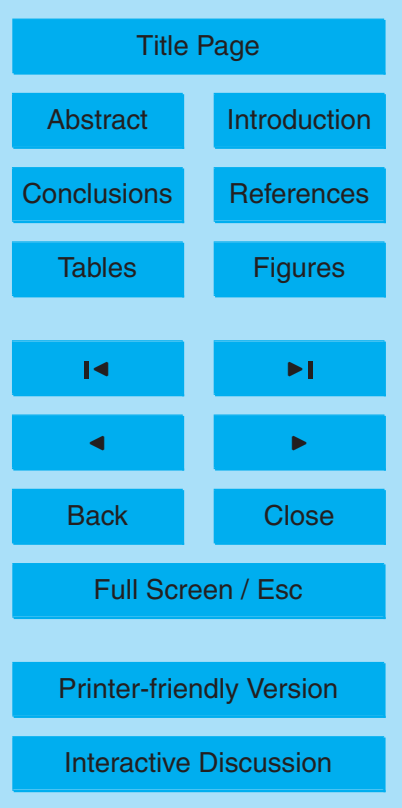


NOAA P3 detects $B C$ cores in the size range of $\approx 90-600 \mathrm{~nm}$ volume equivalent diameter (VED, assuming a density of $2.0 \mathrm{~g} / \mathrm{cc}$ ) irrespective of $B C$ mixing state or morphology with precision of $15 \%$ (Cross et al., 2010). The NOAA results were scaled by a factor of 1.1 to represent the total $B C$ concentration in the accumulation mode.

5 The SP2 instrument on the NASA DC8 was operated by the University of Tokyo and detected $B C$ over a wider size range $(\approx 80-860 \mathrm{~nm})$ than that on the NOAA P3. The $\mathrm{BC}$ mass was calculated for full size range using a lognormal fit and was provided in units $\mathrm{ng} / \mathrm{m}^{3}$. The estimated uncertainty is $\approx 10 \%$.

During YAK-AEROSIB, equivalent black carbon (EBC) mass concentration was mea10 sured using an aethalometer based on diffuse attenuation of light by particles after collection on a filter (Panchenko et al., 2000; Paris et al., 2009). The wavelength ranges between 400 and $1100 \mathrm{~nm}$ with maximum near $900 \mathrm{~nm}$. The instrument is sensitive to submicron particles. EBC mass concentration is calculated from light absorption as described in Paris et al. (2009). The sensitivity of the aethalometer is $\approx 10 \mathrm{ng} / \mathrm{m}^{3} \mathrm{EBC}$.

The SP2 measurements of BC mass loadings generally agreed to within stated uncertainties during wingtip-to-wingtip intercomparisons between the NOAA and NASA aircraft (G. Chen, private communication, 2010). The Arctic vertical profiles from all the SP2 measurements are shown in the context of a measurement-model intercomparison in Fig. 10 of Koch et al. (2009). In their study differences between the different campaigns are likely due to the different sampling of airmasses, as discussed below.

\subsection{Source regions using FLEXPART trajectories}

Backward trajectories from the FLEXPART model (Fuelberg et al., 2010) were used to identify the source region of ARCTAS-A and ARCTAS-B observations. We define the source of each single measurement to be the region where the 10-day back-trajectory remained for the longest time before it reached below $2 \mathrm{~km}$ of the ground. For measurements at or below $2 \mathrm{~km}$ we considered the location of the back-trajectories for 5 days (see Fig. 2). The source region as defined here is often in agreement with the origin of the 10-day back-trajectories (as defined in the caption of Fig. 2). However,

Source contributions to NH CO and black carbon during spring and summer 2008

S. Tilmes et al.

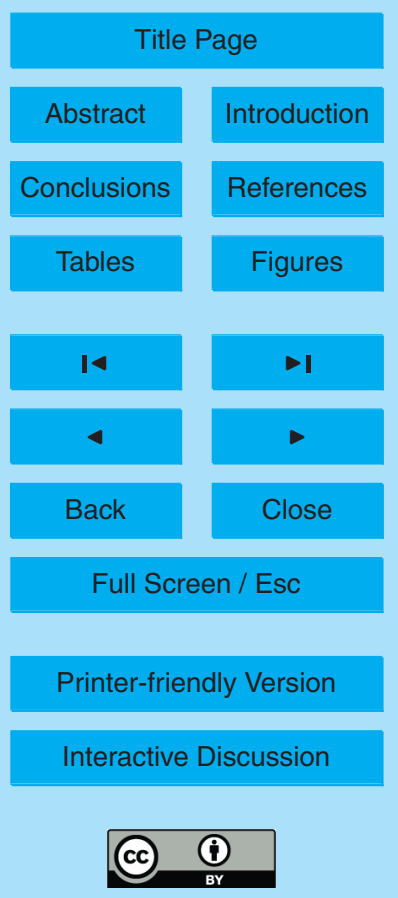


differences occur, for example for those airmasses that originated in Europe but traveled for a few days over China or Siberia, where they experienced large contributions of anthropogenic or fire emissions. Using information of the source region of airmasses are helpful to analyze differences between model results and observations, and dis5 crepancies can be assigned to airmasses that are influenced by pollution from specific source regions. For example, MOZART-4 often underestimates high $\mathrm{CO}$ plumes with an origin in East Siberia, as shown in Fig. 2 (bottom panel).

\subsection{MOPITT satellite data}

MOPITT is a gas-filter correlation radiometer onboard the EOS Terra satellite and has provided observations since March 2000. V4 retrievals of $\mathrm{CO}$ profiles and total columns are used in this study (Deeter et al., 2010). For evaluation of the model results, the MOPITT retrieval averaging kernels and a priori information are used to transform model CO profiles for comparison with MOPITT profiles, as described in Emmons et al. (2010).

\subsection{The MOZART-4 model}

The Model for Ozone and Related chemical Tracers, Version 4 (MOZART-4) was used to simulate the period between March and July 2008. MOZART-4 is an offline global chemical transport model (Emmons et al., 2010). We used dynamic fields from the National Centers for Environmental Prediction (NCEP) Global Forecast System (Kanamitsu et al., 1991) to drive the model with a horizontal resolution of $1.4^{\circ} \times 1.4^{\circ}$ and 64 layers up to $40 \mathrm{~km}$. The model run was performed for the period March-July 2008, with a spin-up of the run starting in July 2007 at $2.8^{\circ} \times 2.8^{\circ}$ resolution. The chemical mechanism describes the most important reactions in the troposphere including the representation of non-methane hydrocarbons, an online calculation of aerosols, and

an online photolysis scheme (Emmons et al., 2010).

\section{ACPD}

11, 5935-5983, 2011

Source contributions to NH CO and black carbon during spring and summer 2008

S. Tilmes et al.

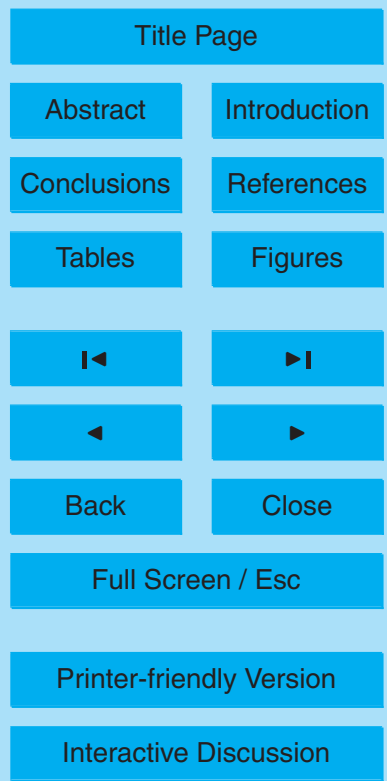


Anthropogenic emissions were taken from the inventory compiled by Qiang Zhang and David G. Streets. This emission inventory it is built upon the INTEX-B inventory (Zhang et al., 2009) with additional data from other sources to make up $\mathrm{NH}$ emissions (see http://www.cgrer.uiowa.edu/arctas/emission.html for more information). 5 Emissions of gases and particles from open burning were calculated using the Fire INventory from NCAR version 1; an emission framework method based on Wiedinmyer et al. $(2006,2010)$, using fire counts (MODIS Data Processing System) provided by the University of Maryland (e.g., Giglio and Descloitres, 2003) for the year 2008. Further details about the global fire emission inventory can be find in Wiedinmyer et al. (2010). 10 Total CO in MOZART-4 can be divided into CO directly emitted from fire and anthropogenic emissions and the photochemically produced $\mathrm{CO}$ from the oxidation of methane and hydrocarbons. The contribution from methane oxidation (on average about $25 \%$ of total $\mathrm{CO}$ ) is fairly uniform spatially and temporally, so is treated as background. CO produced from hydrocarbons emitted from fire and anthropogenic sources are strongly correlated with the direct $\mathrm{CO}$ emissions from those sources. Therefore, the contributions of different source regions to chemically produced $\mathrm{CO}$ are expected to scale similarly as the directly emitted $\mathrm{CO}$. The $\mathrm{CO}$ tags in the simulation shown below are based on direct emissions and do not include chemically produced $\mathrm{CO}$, but this does not change the partitioning of the total sources.

20 Global $\mathrm{CO}$ sources of both anthropogenic and fire emissions (summarized in Table 2) agree well, in general, with the results in Fisher et al. (2010). The largest differences are for anthropogenic emissions for Europe ( $3 \mathrm{Tg} /$ month lower) and for the US (1.5 $\mathrm{Tg} / \mathrm{month}$ greater). Fire emissions vary daily and have a large seasonal variability, as listed for April and July in Table 2. In comparison to previous years, the 2008 fire emissions from Siberia are relatively high in April but relatively low in summer (e.g., van der Werf et al., 2008).

Black carbon and organic carbon aerosols are emitted in a combination of hydrophobic and hydrophilic forms ( $80 \%$ and $50 \%$ hydrophobic, respectively) in MOZART-4. Hydrophobic black carbon is chemically transformed into hydrophilic forms with a lifetime

\section{ACPD}

$11,5935-5983,2011$

Source contributions to NH CO and black carbon during spring and summer 2008

S. Tilmes et al.

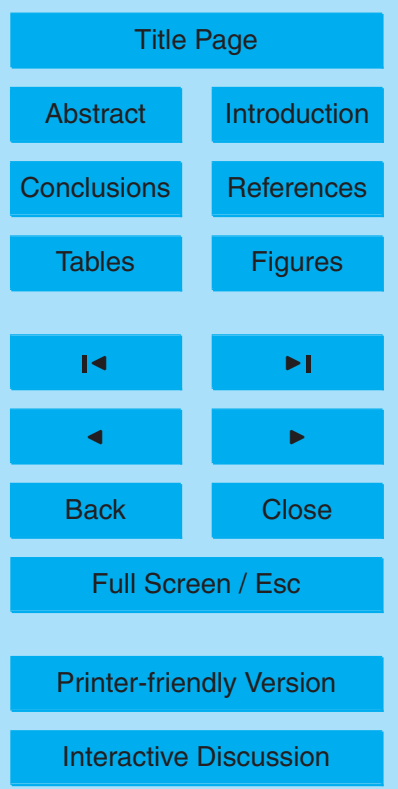


of 1.6 days (as in Horowitz, 2006). In the simulation used here, fire emissions were injected at the surface. This approach might result in an underestimation of concentrations at higher altitudes, since the strong convection that is possible during fires has not been included here (Val Martin et al., 2010). However, in MOZART-4 emissions are

5 effectively transported out of the boundary layer and no significant differences occur between this simulation and an approach where the fire emissions are injected evenly between the surface and $6 \mathrm{~km}$, as also found in Pfister et al. (2005).

Besides the usual tropospheric species, 22 artificial $\mathrm{CO}$ and $\mathrm{BC}$ tracers were added to the simulation, describing the contribution of $\mathrm{CO}$ and $\mathrm{BC}$ from predefined source 10 regions (Fig. 3). The region labeled "China" includes China, Korea and Japan, but the majority of $\mathrm{CO}$ and $\mathrm{BC}$ emissions are from China. For each region two $\mathrm{CO}$ and $\mathrm{BC}$ tags were included, one describing fire emissions and the other describing anthropogenic emissions in each region. The tagging of $\mathrm{CO}$ and $\mathrm{BC}$ allows identification of source contributions to observed species.

To compare MOZART-4 to aircraft data, we interpolated the 6-h model output to the flight tracks of one-minute aircraft observations for the POLARCAT campaigns and of one-second observations for the START08/preHIPPO campaign. Besides CO and BC, $\mathrm{CO}$ and $\mathrm{BC}$ tags are also sampled on the flight tracks for all aircraft data to analyze the contribution of different regions and emission types for both compounds.

\section{Importance of $\mathrm{CO}$ and $\mathrm{BC}$ source regions for different aircraft campaigns}

Aircraft campaigns during POLARCAT and START08/pre-HIPPO were conducted in different regions and periods, as described above. To determine model accuracy, we consider aircraft data during selected periods in spring and summer that are influenced by different pollution factors, as summarized in the following (see also Table 1).

\section{ACPD}

$11,5935-5983,2011$

Source contributions to NH CO and black carbon during spring and summer 2008

S. Tilmes et al.

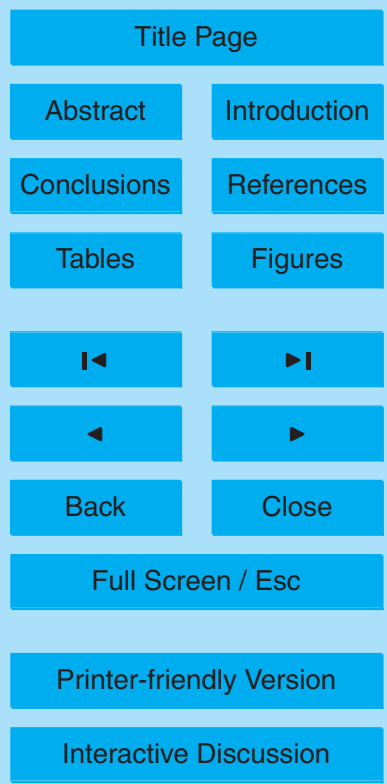




\subsection{High latitudes Spring Campaigns: ARCTAS 4-9 April and POLARCAT-FRANCE 1-11 April 2008}

Between 1 and 11 April, ARCTAS and POLARCAT-France aircraft observations sampled high northern latitudes. The western Arctic and Alaska were hardly influenced 5 by fire emissions, as determined by the model, see for example one day in early April (Fig. 4, top row). Agricultural fires in eastern Europe and west Siberia had started already by April (Warneke et al., 2009), however, by this time only very few plumes with high $\mathrm{CO}$ and $\mathrm{BC}$ values could be identified over North America using FLEXPART trajectories for ARCTAS (not shown). On the other hand, Siberian fire emissions show 10 an influence in northern Europe (Fig. 4, top row left panel) in addition to a large impact of anthropogenic emissions from Eastern Asia and Europe, as discussed in de Villiers et al. (2010) using POLARCAT-France observations. Also, East-Asian fire plumes are occasionally transported into high northern latitudes and contribute slightly to total CO (Fig. 4, top row, right panel). Depending on the location where measurements were taken, the importance of fire emissions in early April can vary greatly.

Since fire emissions are not a very important contributor for ARCTAS CO and BC measurements in early April (with less than 3 ppbv $\mathrm{CO}$ and $3 \mathrm{ng} / \mathrm{m}^{3} \mathrm{BC}$ below $6 \mathrm{~km}$ for single fire tags), a large part of the differences between model and observations at high latitudes in spring can be attributed to anthropogenic emissions (Fig. 5, first and fourth column). The median of simulated CO profiles during this period is $\approx 10 \%$ smaller than observed. CO tags for ARCTAS show the largest contribution of anthropogenic emissions with source regions of China (more than $20 \mathrm{ppbv}$ ), followed by Europe and the US ( $\approx 15 \mathrm{ppbv})$. CO fire contributions are small, as described above. European CO contributions to the POLARCAT-France $\mathrm{CO}$ observations are larger at lower altitudes

(up to $6 \mathrm{~km}$ ) than those from China. Chinese anthropogenic $\mathrm{CO}$ contributions are similar to those calculated for the ARCTAS campaign. A large impact of US anthropogenic emissions (25 ppbv) is identified at altitudes above $6 \mathrm{~km}$. A significant influence of Siberian fire emissions is not simulated by the model for areas investigated during
Source contributions to NH CO and black carbon during spring and summer 2008

S. Tilmes et al.

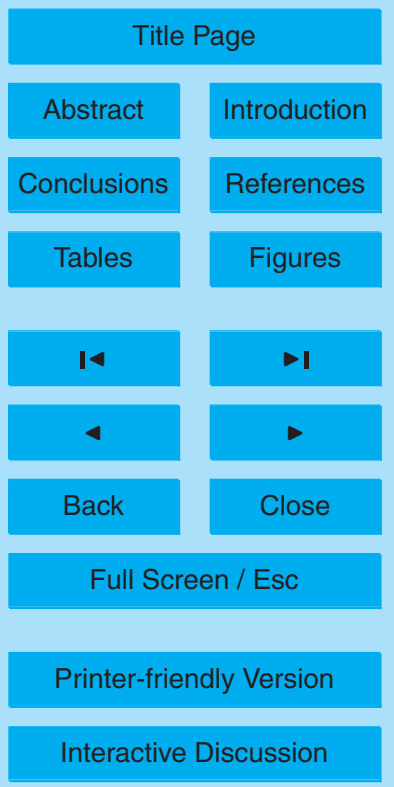


POLARCAT-France. Differences of more than $10 \%$ between modeled and observed CO median profiles for POLARCAT-France point to an additional underestimation of the model, either as a result of the impact of Siberian fire emissions in Northern Europe or due to an additional underestimation of anthropogenic emissions coming from

5 Europe in the beginning of April. An indicator for a reasonable simulation of the impact of fire emissions is the good agreement of the 95th percentile of the $\mathrm{CO}$ distributions between model and observations.

The median of simulated $B C$ is up to $25 \mathrm{ng} / \mathrm{m}^{3}$ smaller in comparison to the ARCTAS aircraft observations (Fig. 5, first column, third and fourth row). A large underestima10 tion of the model occurs for maximum BC values, which are ascribed to airmasses influenced by biomass burning from Russia (Matsui et al., 2011). BC tags show the largest contribution of anthropogenic emissions from China at altitudes above $6 \mathrm{~km}$. Interestingly, US anthropogenic CO shows maximum values between 2 and $8 \mathrm{~km}$ and has a similar vertical structure as the observed maximum BC peaks. CO contributions 15 from Europe are dominant at altitudes below $5 \mathrm{~km}$.

\subsection{High latitudes Spring Campaigns: ARCTAS 12-17 April and ARCPAC 11-21 April 2008}

During 11-21 April, high North American latitudes were strongly influenced by fire plumes coming from Siberia (see Fig. 5, second and third column). ARCPAC flight 20 tracks were mostly concentrated over Alaska and the sea-ice north of Alaska, where the influence of West-Siberian fire emissions was more pronounced than in the sampling region of ARCTAS-A. Anthropogenic CO contributions are 3-4 times larger than from fire emissions similar to the earlier period considered. The model results suggest that ARCTAS-A aircraft data are also strongly influenced by Southeast Asian fire emis-

25 sions and anthropogenic emissions with a maximum in the upper troposphere around $9 \mathrm{~km}$, in correlation to BC contributions from East-Siberian fires and anthropogenic emissions. The fire BC contribution from Siberia has the same magnitude as anthropogenic emissions from Europe between 2 and $5 \mathrm{~km}$. At around $10 \mathrm{~km}$, Indian fire and

\section{Source contributions to $\mathrm{NH} \mathrm{CO}$ and black carbon during spring and summer 2008}

S. Tilmes et al.

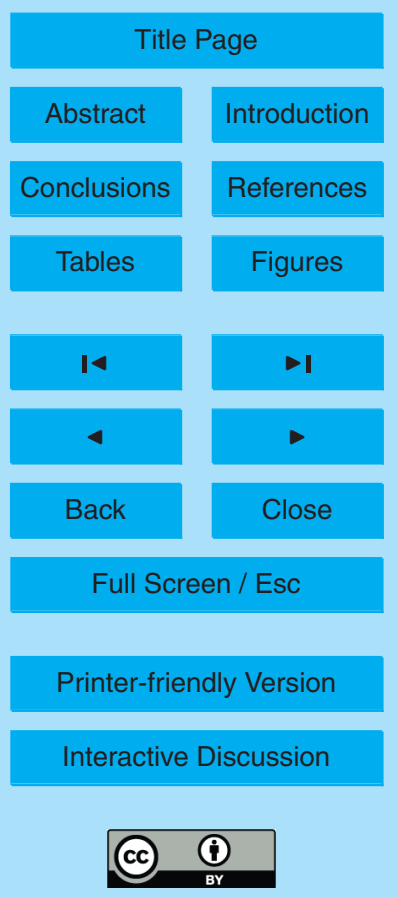


anthropogenic contributions are important as well.

A large discrepancy of $\approx 15 \%$ in CO between model and observations occurs for both aircraft campaigns. For the ARCPAC campaigns this difference is even larger. Since we assume an underestimation of the contribution of anthropogenic emissions

5 of $\approx 10 \%$, the additional difference between model and observations is ascribed to an underestimation of the impact of fire emissions in high latitudes. BC profiles are greatly underestimated on average between 2 and $8 \mathrm{~km}$ and very high $\mathrm{BC}$ values are not simulated. Differences between model and observations are especially large for the ARCTAS campaign. Here, the model underestimates BC median values by more 10 than $50 \%$ between 3 and $6 \mathrm{~km}$. On the other hand, the model largely overestimates $\mathrm{BC}$ above $\approx 8 \mathrm{~km}$ by about 1 order of magnitude, very likely due to an under-estimation of wet scavenging of $B C$ in the model. Matsui et al. (2011) have shown that a smaller contribution of $\mathrm{BC}$ from Asian anthropogenic emissions compared to fire emissions in the Arctic is a result of different transport pathway and experience of precipitation of 15 airmasses.

Using FLEXPART trajectories as described above, we identify measurements that sample airmasses with different origins and highlight them in Fig. 6, China (cyan, left column), Siberia (orange, middle column) and Europe (green, right column). Airmasses with the source region in Alaska and Canada are shown in black in all panels.

20 ARCTAS $\mathrm{CO}$ and $\mathrm{BC}$ profiles show high $\mathrm{CO}$ mixing ratios at around $6 \mathrm{~km}$ coming from East Siberia in this period (see Fig. 6, middle panel). Airmasses from Europe impact altitudes of $3-8 \mathrm{~km}$ for $\mathrm{CO}$ and $\mathrm{BC}$ (right panel). Further, the impact of $\mathrm{CO}$ emissions from China can be allocated to higher altitudes (around $8-10 \mathrm{~km}$ ) as illustrated on the left. This result is consistent with studies by Paris et al. (2008), who observed enhancements of $\mathrm{CO}$ over Siberia due to Chinese emissions lofted by a cold front in a warm conveyor belt in April 2006. Another YAK-AEROSIB campaign in spring 2010 also identified enhanced $\mathrm{CO}$ mixing ratios coming from China at altitudes above $4 \mathrm{~km}$. The shape of the simulated CO median profiles is therefore similar to the one observed and attributed using the FLEXPART model, which points to a reasonable

\section{ACPD}

$11,5935-5983,2011$

Source contributions to NH CO and black carbon during spring and summer 2008

S. Tilmes et al.

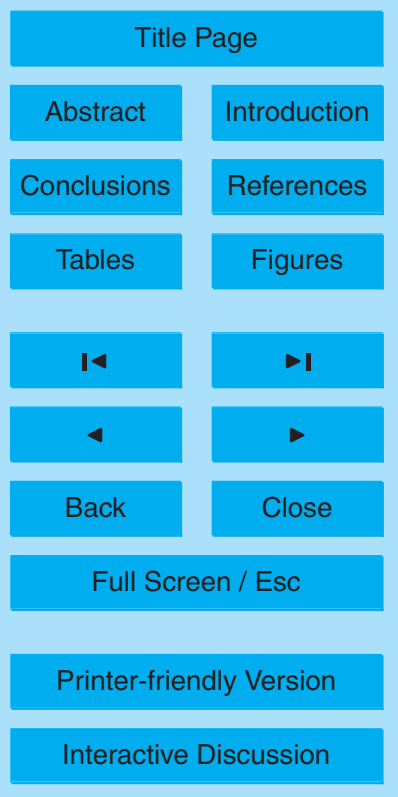

5949 
altitude determination of the influence of fire emissions in MOZART-4, but an underestimation of the magnitude.

The underestimation of simulated $\mathrm{CO}$ at high latitudes is also present in the comparison of MOZART-4 to MOPITT satellite observations. A ten-day average of MOPITT

5 satellite data over this period shows enhanced $\mathrm{CO}$ values in East Siberia and over the Pacific Ocean at $400 \mathrm{hPa}(\approx 6 \mathrm{~km})$, reaching high latitudes (Fig. 7, top panel). Meteorological conditions resulted in the transport of large amounts of pollution from Asia into high latitudes towards Alaska in spring 2008 (Fuelberg et al., 2010). Differences between MOZART-4 and MOPITT show a significant underestimation of $\mathrm{CO}$ mixing ratios 10 at $400 \mathrm{hPa}$ by the model, especially over Alaska. This supports the findings from aircraft observations that the influence of Siberian fire emissions over Alaska and Canada is underestimated in the model. On the other hand, Southeast Asian CO emissions are overestimated at $400 \mathrm{hPa}$ (around $6 \mathrm{~km}$ ), influencing mid-latitude CO values in North America (as further discussed below).

\subsection{Summer Campaigns: ARCTAS-CARB, 18-24 June and ARCTAS B, 26 and 29 June, 10-13 July}

The observations from ARCTAS-CARB campaign (sampled over California between 33 and $41^{\circ} \mathrm{N}$ ), are compared to the observations from those ARCTAS B flights that mainly sampled the mid-latitudes (between $33-70^{\circ} \mathrm{N}$ ). The MOZART-4 CO results show good agreement with the $\mathrm{CO}$ profiles sampled during the ARCTAS-CARB and ARCTAS-B flights at mid-latitudes (Fig. 8). The highest observed $\mathrm{CO}$ mixing ratios in the free troposphere are not reproduced by the model, whereas surface $\mathrm{CO}$ mixing ratios are overestimated by MOZART-4. In general, the contribution of anthropogenic influence on the total $\mathrm{CO}$ that built up over the winter decreases in summer, due to higher $\mathrm{OH}$ concentrations and consequently shorter lifetime of CO (see Table 3). CO tags show a large contribution of US anthropogenic emissions within the first $2 \mathrm{~km}$ above the surface. Above $2 \mathrm{~km}$, anthropogenic emissions from China are dominant. Concentrations from Indian anthropogenic emissions show almost the same magnitude as

Source contributions to NH CO and black carbon during spring and summer 2008

S. Tilmes et al.

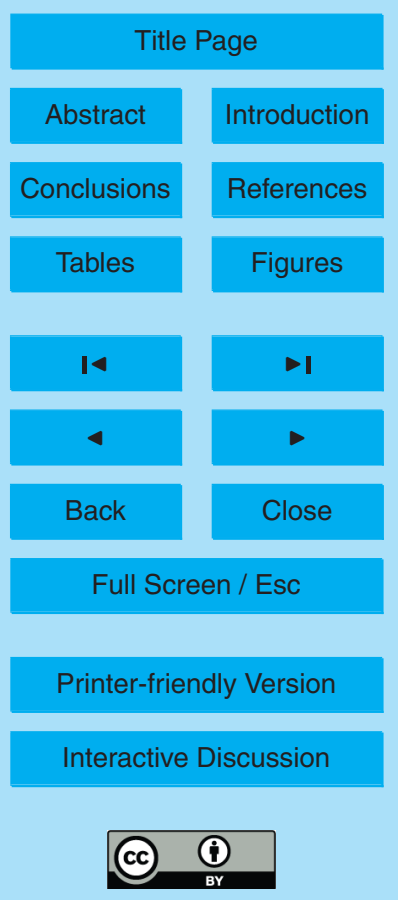


contributions from Europe and the US. ARCTAS-B mid-latitude aircraft data are more influenced by US and East-Siberian fire emissions than ARCTAS-CARB also at midlatitudes. As for $\mathrm{CO}, \mathrm{BC}$ is overestimated in MOZART-4 at altitudes below $2 \mathrm{~km}$ where the largest contributions come from US anthropogenic and fire emissions. The largest 5 BC contribution at 3-4 km for ARCTAS-CARB is the influence of anthropogenic emissions from our Central America region, which includes most of Mexico. Above $4 \mathrm{~km}$, $\mathrm{BC}$ is overestimated by the model, likely a result of missing $B C$ scavenging in higher altitudes that occurs during the wet season in China.

\subsection{High Latitude Summer Campaigns: ARCTAS-B, GRACE, POLARCAT-France and YAK-AEROSIB}

At high latitudes in summer, ARCTAS-B CO median profiles are underestimated by up to 40 ppbv (Fig. 9). Maximum BC and $\mathrm{CO}$ mixing ratios are also strongly underestimated, especially below $4 \mathrm{~km}$, suggesting the underestimation of the impact of Canadian fire emissions. POLARCAT GRACE and POLARCAT-France aircraft campaigns 5 show better agreement between observations and model results, with differences of $\pm 10-15$ ppbv CO. POLARCAT GRACE median CO is overestimated by the model at altitudes below $6 \mathrm{~km}$. On the other hand, the model underestimates $\mathrm{CO}$ above $6 \mathrm{~km}$ and maximum $C O$ values of more than 150 ppbv are not reproduced. For YAK-AEROSIB, $\mathrm{CO}$ contributions are significantly overestimated by $\approx 20 \mathrm{ppbv}$ at altitudes below $6 \mathrm{~km}$, 20 as discussed below.

As for the mid-latitudes, Chinese anthropogenic emissions show the largest fraction in the total amount during ARCTAS-B (Fig. 9, first column). With up to $10 \mathrm{ppbv}$ $\mathrm{CO}$, US and European anthropogenic emissions are as important as Chinese emissions for the campaigns that took place over Greenland and Europe (Fig. 9, third and

fourth column). In all high latitude summer campaigns, East-Siberian fire contributions reach the magnitude of US and European anthropogenic emissions ( $\approx 5 \mathrm{ppbv})$. Similar to ARCTAS-CARB, BC concentrations for ARCTAS-B agree for low altitudes, where Canadian fires are important. In low altitudes, fresh fire plumes of Alaska and 5951

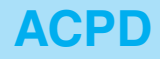

$11,5935-5983,2011$

Source contributions to $\mathrm{NH} \mathrm{CO}$ and black carbon during spring and summer 2008

S. Tilmes et al.

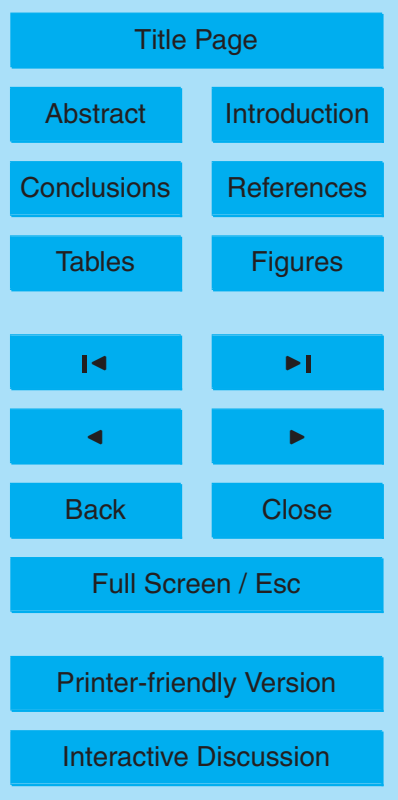

Interactive Discussion 
Canadian fires contribute largely (up to $30 \mathrm{ppbv} \mathrm{CO}$ and $50 \mu \mathrm{g} / \mathrm{m}^{3} \mathrm{BC}$ ) to the amount of $\mathrm{CO}$ and $\mathrm{BC}$.

FLEXPART trajectories calculated for each measurement of ARCTAS-B aircraft data (Fig. 10) indicate the contribution of large amounts of $\mathrm{CO}$ from East Siberia at altitudes 5 around $8 \mathrm{~km}$ in summer high latitudes and from China around $10 \mathrm{~km}$, in agreement with simulated $\mathrm{CO}$ tags (shown in Fig. 9). As discussed above, BC values are very low above $5 \mathrm{~km}$ compared to the corresponding $\mathrm{CO}$ values. Wet scavenging likely results in the loss of $\mathrm{BC}$ coming from Asia and is therefore not correlated with the high $\mathrm{CO}$ mixing ratios. In summer, airmasses from Alaska and Canada show very large CO 10 and $\mathrm{BC}$ values, especially at altitudes below $4 \mathrm{~km}$. Enhanced airmasses from Alaska and Canada are also identified in higher altitudes above $5 \mathrm{~km}$, especially for CO (up to $220 \mathrm{ppbv}$ ). The underestimation of $\mathrm{CO}$ above $5 \mathrm{~km}$ by the model for the ARCTAS-B period is therefore, at least in part, the result of an underestimation of the impact of Canadian fire emissions on higher altitudes. This can be due to an underestimation 15 of fire emissions or shortcomings in the model transport not bringing sufficient $\mathrm{CO}$ to higher altitudes.

To further understand the large discrepancy between $\mathrm{CO}$ observations and model results in summer high latitudes, we compare the MOZART-4 results to MOPITT CO retrievals for the 800 and $400 \mathrm{hPa}$ level. A significant overestimation of Siberian fires at 20 $800 \mathrm{hPa}$ (see Fig. 12) is in agreement with the overestimation of $\mathrm{CO}$ mixing ratios during the YAK-AEROSIB campaign, which samples fresh Siberian fires. At $400 \mathrm{hPa}$, large values of $\mathrm{CO}$ mixing ratios occur over the western Pacific Ocean. East-Siberian fire emissions are likely lofted up to the upper troposphere and transported over the Pacific Ocean towards high North American latitudes. The comparison between MOZART-4 25 and MOPITT also shows a large underestimation of North American surface emissions, as well as an underestimation of $\mathrm{CO}$ mixing ratios at the $400 \mathrm{hPa}$ altitude level. The CO differences of about $30 \%$ between MOZART-4 and the ARCTAS-B aircraft measurements in high northern latitudes are therefore an underestimation of North American emissions in summer and likely an underestimation of the remote influence of

\section{ACPD}

11, 5935-5983, 2011

\section{Source contributions to NH CO and black carbon during spring and summer 2008}

S. Tilmes et al.

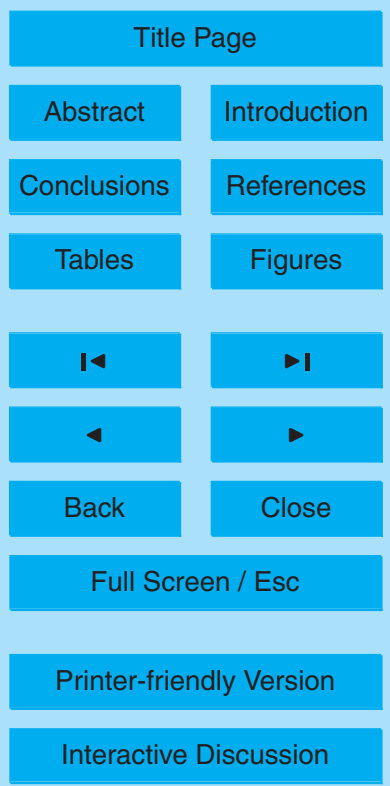


East-Siberian fire emissions in the model simulation. This also influences $\mathrm{CO}$ concentrations over Europe at higher altitudes. However, those differences between observations and model results are much smaller in northern Europe than in North America.

\subsection{Spring and summer mid latitudes: START08 16 April to 17 June 2008}

5 The START08 aircraft campaign took place at latitudes $\approx 30-65^{\circ} \mathrm{N}$. This campaign did not target anthropogenic pollution or forest fires, but provided a broad sampling of the troposphere. Median profiles of aircraft data and MOZART-4 results are in very good agreement for both seasons (Fig. 13). The model shows a large contribution of Chinese anthropogenic emissions followed by US and European emissions. At altitudes 10 above $8 \mathrm{~km}$, Indian emissions show the second largest anthropogenic contributions of more than 5 ppbv. Further, fire emissions from China and India are most pronounced in high latitudes with a maximum of more than $10 \mathrm{ppbv}$ for China and $7 \mathrm{ppbv}$ for India around $8 \mathrm{~km}$. CO concentrations from East-Siberian fires reach values up to $10 \mathrm{ppbv}$ around $4 \mathrm{~km}$. The good agreement between aircraft data and model results in spring can be in part a result of two compensating shortcomings of the model: the overestimation of Asian fires and the underestimation of anthropogenic emission in mid-latitudes, as shown above in the comparison between MOPITT and MOZART-4. In summer, Chinese anthropogenic emissions are less important but are still much larger than fire emissions. Only East Siberian fire contributions are of the same magnitude as European fire contributions.

\section{Influence of $\mathrm{CO}$ and $\mathrm{BC}$ anthropogenic and fire emission for the entire $\mathrm{NH}$}

We use the MOZART-4 model to derive the contribution of fire and anthropogenic emissions of different source regions to the $\mathrm{NH}$. Absolute and relative contributions of source regions were calculated using the simulated $\mathrm{CO}$ and $\mathrm{BC}$ tags for the de-

fined regions, as shown in Fig. 3. Uncertainties between model and observations, as
ACPD

$11,5935-5983,2011$

Source contributions to NH CO and black carbon during spring and summer 2008

S. Tilmes et al.

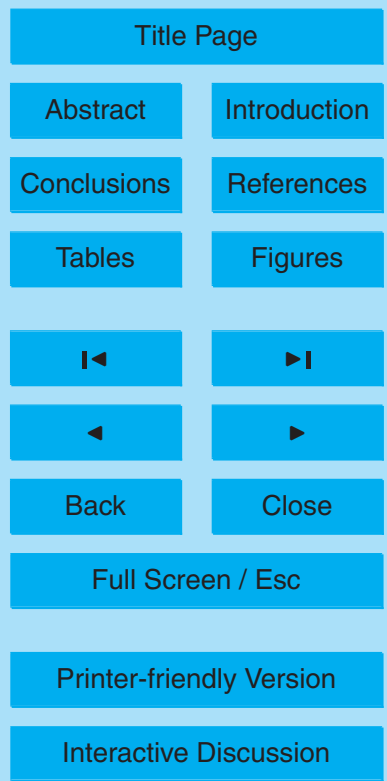


discussed in Sect. 3 have to be kept in mind as a caveat. First, we discuss the altitude distribution of zonally averaged relative contributions of $\mathrm{CO}$ and $\mathrm{BC}$ for both anthropogenic and fire emissions for April and July (Figs. 14 and 15). Only the four regions with the largest $\mathrm{CO}$ and $\mathrm{BC}$ contributions are shown.

5 Anthropogenic pollution dominates $\mathrm{CO}$ mixing ratios from wildfire and agricultural burning emissions in the entire $\mathrm{NH}$. The largest fraction of $\mathrm{CO}$ pollution comes from China with up to $18 \%$ in April and $15 \%$ in July in high latitudes. The altitude distribution shows that emissions are lofted up to $12 \mathrm{~km}$ over China and get transported toward high latitudes, where they descend. This process occurs from the influence of the 10 warm conveyor belts over China, as discussed above. CO contributions from Europe and the US reach up to $16 \%$ and $12 \%$, respectively. CO emissions are also transported towards high latitudes but stay at lower altitudes, which results in a maximum contribution between 0 and $4 \mathrm{~km}$ for these source regions. Indian anthropogenic emissions are stronger in summer than in spring, in contrast to those from China, Europe and the US. The high CO values at high altitudes (above $12 \mathrm{~km}$ ) are very likely a result of the Indian monsoon that occurs at around $30^{\circ} \mathrm{N}$. Some of those emissions are transported towards high latitudes and contribute $(\approx 5 \%)$ to the entire $\mathrm{CO}$ abundance in the Arctic region.

The largest $\mathrm{CO}$ contributions from forest fires are denoted in Siberia and Southeast 20 Asia during July and April, respectively. The impact of other fires on the total $\mathrm{CO}$ in the zonal average can be neglected. In April, the strongest contribution of forest fires comes from China and Southeast Asia. However, only little CO contribution from China and East Asia is found in high latitudes at altitudes around $10 \mathrm{~km}$. In spring, Siberian fires have a smaller percentage contribution to the total $\mathrm{CO}$ at the latitude of their source (around $40-50^{\circ} \mathrm{N}$ ) compared to summer, even though $\mathrm{CO}$ emissions are larger in April compared to July (see Table 2). Due to the shorter lifetime of $\mathrm{CO}$, anthropogenic emissions have reduced importance in summer compared to spring (see Table 3). In summer, the contribution of Siberian fires to high latitude pollution is very pronounced and almost reaches levels of anthropogenic pollution in summer at altitudes around

\section{ACPD}

$11,5935-5983,2011$

Source contributions to NH CO and black carbon during spring and summer 2008

S. Tilmes et al.

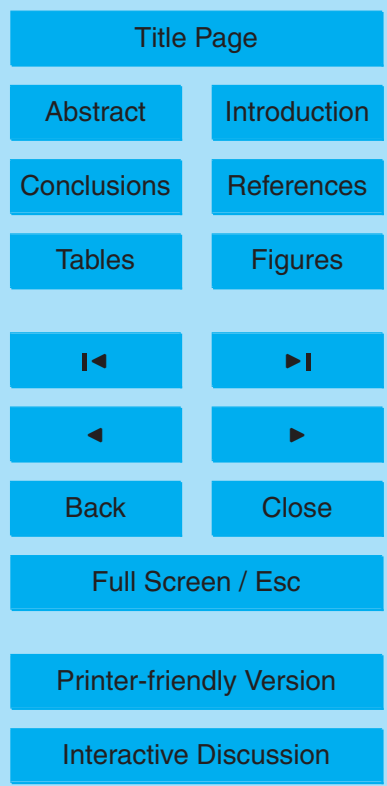


$6 \mathrm{~km}$. In July, the relative contribution of East-Siberian fire emissions exceeds those from anthropogenic emissions coming from China.

The percentage anthropogenic contribution of $\mathrm{BC}$ is much larger than for $\mathrm{CO}$, since $\mathrm{BC}$ is not photochemically produced, as is the case for $\mathrm{CO}$. The altitude distributions 5 of $\mathrm{BC}$ and $\mathrm{CO}$ are very similar. East-Siberian emissions show the strongest influence in high latitudes between $0-8 \mathrm{~km}$. As opposed to $\mathrm{CO}$, the relative contribution of anthropogenic emissions coming from all considered source regions increases between April and July. BC is not chemically destroyed but it is lost by washout, which is seasonally dependent. The lifetime of anthropogenic BC emissions therefore depends on 10 the season.

The absolute and relative contribution of column $\mathrm{CO}$ and $\mathrm{BC}$ is summarized in Fig. 16. In spring, about half of the total $\mathrm{CO}$ is a result of photochemical production (hydrocarbon oxidation); in summer this is even more than half. The only source for $\mathrm{BC}$ is assumed to be surface emissions. Total emissions of $\mathrm{BC}$ maximize in mid15 latitudes and strongly decrease towards high latitudes. In spring, $70 \%$ of both $\mathrm{CO}$ and $\mathrm{BC}$ contributions are from anthropogenic sources in mid and high latitudes. China shows the largest contribution for both $\mathrm{CO}$ and $\mathrm{BC}$ with $\approx 18 \%$, followed by Europe and the US. In low latitudes (around $20^{\circ} \mathrm{N}$ ) in spring, fire emissions reach $40 \%$ for $\mathrm{CO}$ and $60 \%$ for BC. The main contributions are Chinese, Indian and Southeast Siberian fires. At $0-20^{\circ} \mathrm{N}$, North African emissions contribute significantly to the entire $\mathrm{CO}$ and $\mathrm{BC}$ distributions. In high latitudes, the largest $\mathrm{BC}$ fire contributions are from Siberia, whereas other regions are equally important for the CO fire contributions. In summer, East-Siberian fires dominate the contribution of fire emissions in high latitudes, with up to $30 \%$ for $\mathrm{CO}$ and $20 \%$ for BC. Fire emissions in low latitudes (around $20^{\circ} \mathrm{N}$ ) are less important in July, whereas close to the equator the contribution of fire emissions of the $\mathrm{SH}$ reach up to $40 \%$ for $\mathrm{CO}$ and up to $60 \%$ for $\mathrm{BC}$.

\section{ACPD}

$11,5935-5983,2011$

\section{Source contributions to NH CO and black carbon during spring and summer 2008}

S. Tilmes et al.

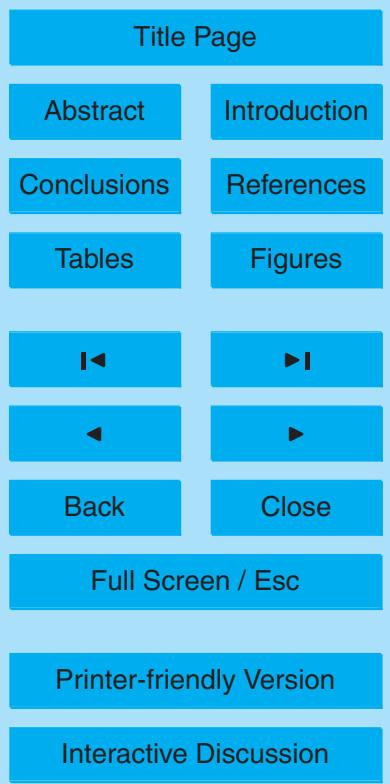




\section{Conclusions}

Aircraft observations from five POLARCAT aircraft campaigns and the START08/preHIPPO mid-latitude campaign were used to analyzed the contributions of $\mathrm{CO}$ and $\mathrm{BC}$ anthropogenic and fire emissions in the NH using the MOZART-4

5 model. Depending on the sampling region of single campaigns considered, the contributions of fire emissions varies significantly, whereas the contributions of anthropogenic emissions is rather similar. The comparison between aircraft observations and model results that are interpolated on the flight track allows the evaluation of the MOZART-4 model with regard to $\mathrm{CO}$ and $\mathrm{BC}$ contributions from different source 10 regions. The performance of the simulated $\mathrm{CO}$ and $\mathrm{BC}$ in spring and summer is summarized in the following:

- Since fire emissions did not significantly influence ARCTAS-A observations at the beginning of April, the difference between model and $\mathrm{CO}$ observations of about $10 \%$ is concluded to be a result of an underrepresentation of anthropogenic emissions. An underestimation of anthropogenic emissions was also found in Fisher et al. (2010) who used a similar inventory.

- During 11-21 April additional discrepancies between simulated and observed CO and $B C$ in high latitudes, as sampled by ARCTAS-A and ARCPAC, is a result of the underestimation of fire plumes coming from East Siberia. Further, POLARCATFrance observations show an underestimation of $\mathrm{CO}$ mixing ratios in Northern Europe in the first part of April, which can be attributed to an underestimation of the remote influence of both fire and anthropogenic emissions. The sampling of model data on the flight tracks might not result in the same tracer characteristics as shown in the data, because observed pollution plumes might be slightly displaced and more strongly diluted in the model and flight track samples (Rastigejev et al., 2010). In addition, MOPITT satellite data point to shortcomings in the transport of fire plumes towards high latitudes.

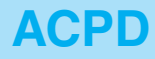

$11,5935-5983,2011$

\section{Source contributions} to NH CO and black carbon during spring and summer 2008

S. Tilmes et al.

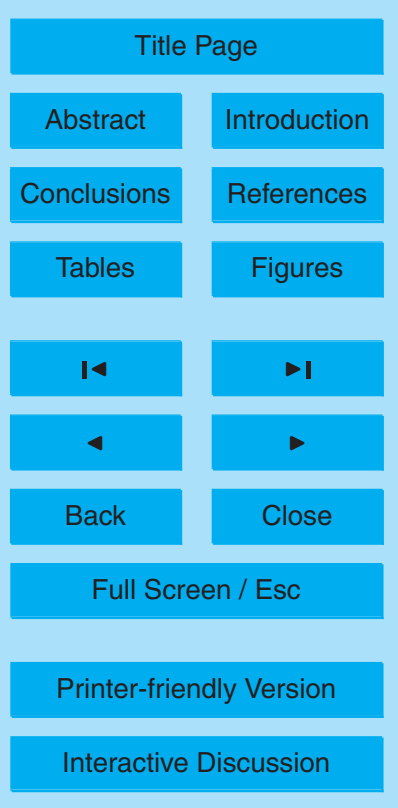


- Mid-latitude CO mixing ratios over North America in spring are influenced by Southeast-Asian fire plumes. The remote influence of East-Asian fire emissions were shown to be too large in the simulation compared to observations, whereas the impact of East-Siberian fire plumes are underestimated in spring. These compensating errors result, on average, in good agreement between observations and MOZART-4 results.

- In summer high northern latitudes, the contribution of anthropogenic emissions is in general less important for $\mathrm{CO}$, due to the shorter lifetime of $\mathrm{CO}$, whereas the amount of total fire emissions gain importance, especially in low- and midlatitudes. Mid-latitude $\mathrm{CO}$ and $\mathrm{BC}$ mixing ratios agree well between model and observations. At high latitudes, discrepancies between model and observations vary with region and altitude. Siberian fires are overestimated by the model, whereas North American emissions, especially Canadian fire emissions are underestimated. This results in an overestimation of $\mathrm{CO}$ for regions that are influenced by Siberian fires and an underestimation of regions that are influenced by North American fire and anthropogenic pollution. BC is overestimated at altitudes above $6 \mathrm{~km}$, partly due to an under-estimation of wet scavenging of $\mathrm{BC}$ during the rainy season in summer over Asia.

In summary, shortcomings of the model simulation occur due to uncertainties induced by transport errors in the model, e.g., problems in the transport of finescale fire plumes to the Arctic, due to too much diffusion of a global model, as discussed in Pisso et al. (2009), but also due to uncertainties in emission inventories. This leads to the underestimation of $\mathrm{CO}$ in high latitudes, especially where fire plumes are important. Simulated mid-latitude $\mathrm{CO}$ mixing ratios agree reasonably well with aircraft observations in spring and summer. Here, the underestimation of anthropogenic emissions is likely compensated by an overestimation of South Asian fire emissions. Further, the anthropogenic amount of $B C$ is reasonably well reproduced by the model in spring, whereas the impact of fires seems to be largely underestimated. MOZART-4 also overestimates

\section{ACPD}

$11,5935-5983,2011$

\section{Source contributions to NH CO and black carbon during spring and summer 2008}

S. Tilmes et al.

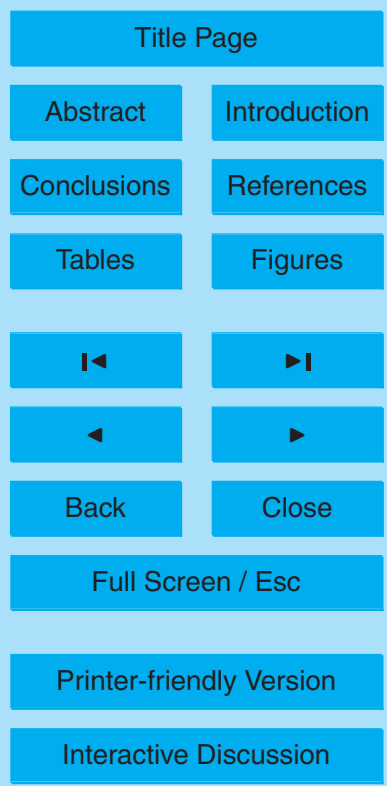


$\mathrm{BC}$ in spring and summer in the upper troposphere, likely as a result of too little wet scavenging of emissions coming from Asia (Matsui et al., 2011).

Contributions of fire emissions and differences between model and observations were shown to vary between different campaigns. Therefore, considering the results 5 of single aircraft campaigns cannot be transferred to the global contributions of $\mathrm{CO}$ and BC. We also provide an overview of zonally averaged contributions for different altitudes and latitudes in the $\mathrm{NH}$. The largest contribution of $\mathrm{CO}$ and $\mathrm{BC}$ comes from Chinese anthropogenic emissions $(\approx 18 \%)$ at high latitudes, followed by European and US emissions. The relative contributions of anthropogenic $\mathrm{CO}$ emissions decreases 10 in summer high latitudes, whereas the BC contribution of anthropogenic emissions is still around $70 \%$. Chinese and Southeast Asian fires largely contribute to the pollution around $20^{\circ} \mathrm{N}$ in spring, whereas Siberian fires show a contribution of up to $30 \%$ in summer. $\mathrm{BC}$ fire contributions are larger in spring compared to $\mathrm{CO}$ but slightly smaller in summer. Different altitude intervals at high latitudes are influenced by different source 15 emissions, depending on the transport pathways of polluted airmasses from different regions.

The transport of $\mathrm{CO}$ and especially $\mathrm{BC}$ into high latitudes can have a significant impact on global radiation, mainly due to the deposition of $B C$ on ice and snow. Further studies are necessary to explore the importance of mid-latitude pollution from different source regions on the Earth's climate.

Acknowledgements. Thanks to Gabriele Pfister and Rebecca Hornbock for helpful comments. The POLARCAT-France project, including ATR-42 flights, were funded by French ANR, CNES, CNRS-INSU, IPEV and EUFAR. The YAK-AEROSIB campaigns were funded in France by the ANR Blanc POLARCAT, CNRS-DERCI, CNRS-INSU, the French Ministry of Foreign Affairs 25 and CEA; in Russia by the RAS and RFBR; and by the Norwegian Research Council as part of POLARCAT-Norway. The campaigns are operated in collaboration with IAO-SB-RAS, Tomsk, Russia. This work was supported by the NASA Tropospheric Chemistry Program under grant NNX08AD22G. The National Center for Atmospheric Research is funded by the National Science Foundation.

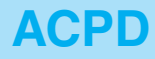

$11,5935-5983,2011$

\section{Source contributions to NH CO and black carbon during spring and summer 2008}

S. Tilmes et al.

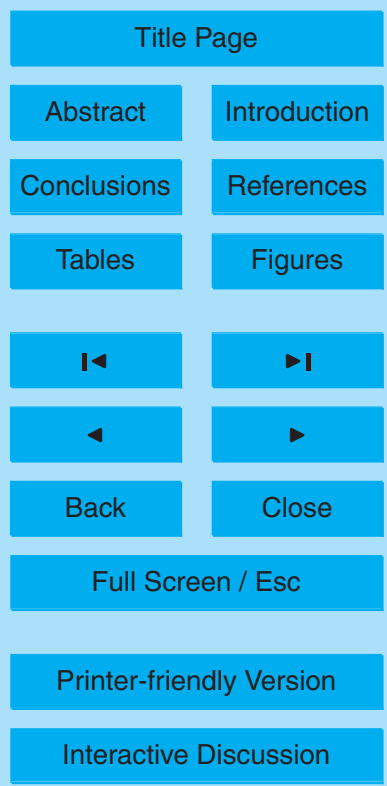




\section{References}

Brock, C. A., Cozic, J., Bahreini, R., Froyd, K. D., Middlebrook, A. M., McComiskey, A., Brioude, J., Cooper, O. R., Stohl, A., Aikin, K. C., de Gouw, J. A., Fahey, D. W., Ferrare, R. A., Gao, R.-S., Gore, W., Holloway, J. S., Hbler, G., Jefferson, A., Lack, D. A., Lance, S., Moore, R. Davies, J., De Backer, H., Dier, H., Dorokhov, V., Gerding, M., Gil, M., Henchoz, B., Kelder, H., Kivi, R., Kyrö, E., Litynska, Z., Moore, D., Peters, G., Skrivankova, P., Stübi, R., Turunen, T., Vaughan, G., Viatte, P., Vik, A. F., von der Gathen, P., and Zaitcev, I.: Regional climate projections, in: Climate change 2007: The physical science basis. contribution of working group I to the fourth assessment report of the Intergovernmental Panel on Climate Change, 2007. 5938

Clarke, A. and Noone, K. J.: Soot in the arctic snowpack: A cause for perturbations in radiative transfer, Atmos. Environ., 19, 2045-2053, 1985. 5938

Cross, E. S., Onasch, T. B., Ahern, A., Wrobel, W., Slowik, J. G., Olfert, J., Lack, D. A., Massoli, P., Cappa,C. D., Schwarz, J. P., Spackman, J. R., Fahey, D. W., Sedlacek, A., Trimborn, A., Jayne, J. T., Freedman, A., Williams, L. R., Ng, N. L., Mazzoleni, C., Dubey, M., Brem, B., Kok, G., Subramanian, R., Freitag, S., Clarke, A., t Thornhill, D., Marr, L., Kolb, C. E., Worsnop, D. R., and Davidovits, P.: Soot particle studies - instrument intercomparison project overview, Aerosol Sci. Technol., 44(8), 592-611 2010. 5943

Deeter, M. N., Edwards, D. P., Gille, J. C., Emmons, L. K., Francis, G., Ho, S.-P., Mao, D., Masters, D., Worden, H., Drummond, J. R., and Novelli P. C.: The MOPITT version 4 CO product: Algorithm enhancements, validation and long-term stability, J. Geophys. Res., 115, D07306, doi:10.1029/2009JD013005, 2010. 5940, 5944

de Villiers, R. A., Ancellet, G., Pelon, J., Quennehen, B., Schwarzenboeck, A., Gayet, J. F., and Law, K. S.: Airborne measurements of aerosol optical properties related to early
Source contributions to NH CO and black

carbon during spring and summer 2008

S. Tilmes et al.

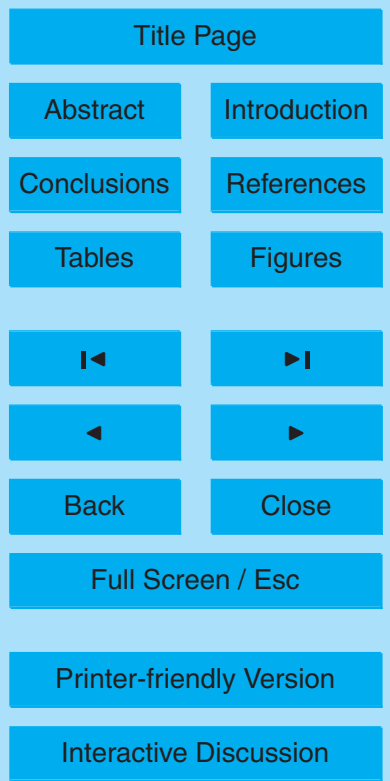


spring transport of mid-latitude sources into the Arctic, Atmos. Chem. Phys., 10, 5011-5030, doi:10.5194/acp-10-5011-2010, 2010. 5939, 5941, 5947

Emmons, L. K., Walters, S., Hess, P. G., Lamarque, J.-F., Pfister, G. G., Fillmore, D., Granier, C., Guenther, A., Kinnison, D., Laepple, T., Orlando, J., Tie, X., Tyndall, G., Wiedinmyer, C.,

$5 \quad$ Baughcum, S. L., and Kloster, S.: Description and evaluation of the Model for Ozone and Related chemical Tracers, version 4 (MOZART-4), Geosci. Model Dev., 3, 43-67, 2010. 5939,5944

Fisher, J. A., Jacob, D. J., Purdy, M. T., Kopacz, M., Le Sager, P., Carouge, C., Holmes, C. D., Yantosca, R. M., Batchelor, R. L., Strong, K., Diskin, G. S., Fuelberg, H. E., Holloway, J. S., Hyer, E. J., McMillan, W. W., Warner, J., Streets, D. G., Zhang, Q., Wang, Y., and Wu, S.: Source attribution and interannual variability of Arctic pollution in spring constrained by aircraft (ARCTAS, ARCPAC) and satellite (AIRS) observations of carbon monoxide, Atmos. Chem. Phys., 10, 977-996, doi:10.5194/acp-10-977-2010, 2010. 5939, 5945, 5956

Flanner, M. G., Zender, C. S., Ramanathan, V., and Rasch, P. J.: Present day climate forcing and response from black carbon in snow, J. Geophys. Res., 112, 2481-2497, 2007. 5938

Flanner, M. G., Zender, C. S., Hess, P. G., Mahowald, N. M., Painter, T. H., Ramanathan, V., and Rasch, P. J.: Springtime warming and reduced snow cover from carbonaceous particles, Atmos. Chem. Phys., 9, 2481-2497, doi:10.5194/acp-9-2481-2009, 2009. 5938

Fuelberg, H. E., Harrigan, D. L., and Sessions, W.: A meteorological overview of the ARC20 TAS 2008 mission, Atmos. Chem. Phys., 10, 817-842, doi:10.5194/acp-10-817-2010, 2010. 5940, 5943, 5950

Giglio, L. and Descloitres, J.: An enhanced contextual fire detection algorithm for modis, Remote Sens. Environ., 87(2-3), 273-282, 2003. 5945

Hansen, J. and Nazarenko, L.: Soot climate forcing via snow and ice albedos, Proc. Natl. Acad. Sci., 423-428, 2004. 5938

Horowitz, L. W.: Past, present, and future concentrations of tropospheric ozone and aerosols: Methodology, ozone evaluation, and sensitivity to aerosol wet removal, J. Geophys. Res., 111, D2211, doi:10.1029/2005JD006937, 2006. 5946

Huang, M., Carmichael, G. R., Adhikary, B., Spak, S. N., Kulkarni, S., Cheng, Y. F., Wei, C., Tang, Y., Parrish, D. D., Oltmans, S. J., D’Allura, A., Kaduwela, A., Cai, C., Weinheimer, A. J., Wong, M., Pierce, R. B., Al-Saadi, J. A., Streets, D. G., and Zhang, Q.: Impacts of transported background ozone on California air quality during the ARCTAS-CARB period - a multi-scale modeling study, Atmos. Chem. Phys., 10, 6947-6968, doi:10.5194/acp-10-6947-2010, 2010.

\section{Source contributions to NH CO and black carbon during spring and summer 2008}

S. Tilmes et al.

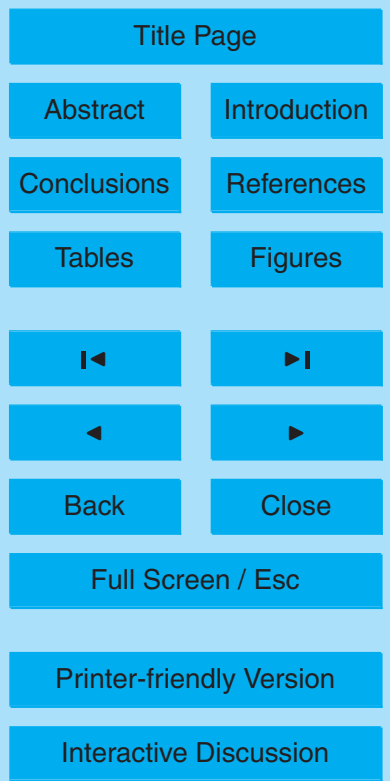


ICARTT: Icartt field campaign observation assessment report, Tech. rep., National Aeronautics and Space Administration (NASA), http://www-air.larc.nasa.gov/TAbMEP.html, 2010. 5942

Jacob, D. J., Crawford, J. H., Maring, H., Clarke, A. D., Dibb, J. E., Emmons, L. K., Ferrare, R.

$5 \quad$ A., Hostetler, C. A., Russell, P. B., Singh, H. B., Thompson, A. M., Shaw, G. E., McCauley, E., Pederson, J. R., and Fisher, J. A.: The Arctic Research of the Composition of the Troposphere from Aircraft and Satellites (ARCTAS) mission: design, execution, and first results, Atmos. Chem. Phys., 10, 5191-5212, doi:10.5194/acp-10-5191-2010, 2010. 5939, 5940

Jacobson, M. Z.: Strong radiative heating due to the mixing state of black carbon in atmospheric aerosols, Nature, 409, 695-697, 2001. 5938

Kanamitsu, M., Alpert, J. C., Campana, K. A., Caplan, P. M., Deaven, D. G., Iredell, M., Katz, B., Pan, H.-L., and White, G. H.: Recent changes implemented into the global forecast system at NMC, Weather Forecast., 1145-1160, 1991. 5944

Kleb, M. M., Chen, G., Belli, K., Crawford, J. H., and Rowell, A. F.: Overview of polarcat in15 tercomparisons, AGU conference presentation, December 2009, http://adsabs.harvard.edu/ labs/2009AGUFM.A43A0187K, 2009. 5942

Koch, D. and Del Genio, A. D.: Black carbon semi-direct effects on cloud cover: review and synthesis, Atmos. Chem. Phys., 10, 7685-7696, doi:10.5194/acp-10-7685-2010, 2010. 5938

Koch, D., Schulz, M., Kinne, S., McNaughton, C., Spackman, J. R., Balkanski, Y., Bauer, S., Berntsen, T., Bond, T. C., Boucher, O., Chin, M., Clarke, A., De Luca, N., Dentener, F., Diehl, T., Dubovik, O., Easter, R., Fahey, D. W., Feichter, J., Fillmore, D., Freitag, S., Ghan, S., Ginoux, P., Gong, S., Horowitz, L., Iversen, T., Kirkevåg, A., Klimont, Z., Kondo, Y., Krol, M., Liu, X., Miller, R., Montanaro, V., Moteki, N., Myhre, G., Penner, J. E., Perlwitz, J., Pitari, G., Reddy, S., Sahu, L., Sakamoto, H., Schuster, G., Schwarz, J. P., Seland, Ø., Stier, P., Takegawa, N., Takemura, T., Textor, C., van Aardenne, J. A., and Zhao, Y.: Evaluation of black carbon estimations in global aerosol models, Atmos. Chem. Phys., 9, 9001-9026, doi:10.5194/acp-9-9001-2009, 2009. 5938, 5943

Kondo, Y., Matsui, H., Moteki, N., Sahu, L., Takegawa, N., Zhao, Y., Cubison, J., Jimenez, J. L., Vay, S., Diskin, G. S., Anderson, B., Wisthaler, A., Mikoviny, T., Fuelberg, H. E., Blake, D. R., Huey, G., Weinheimer, A. J., Knapp, D. J., and Brunell, H.: Emissions of black carbon, organic, and inorganic aerosols from biomass burning in North America and Asia in 2008, J. Geophys. Res., submitted, 2010. 5942

Matsui, H., Kondo, Y., Moteki, N., Takegawa, N., Sahu, L. K., Zhao, Y., Fuelberg, H. E., Ses-

\section{ACPD}

11, 5935-5983, 2011

\section{Source contributions to NH CO and black \\ carbon during spring and summer 2008}

S. Tilmes et al.

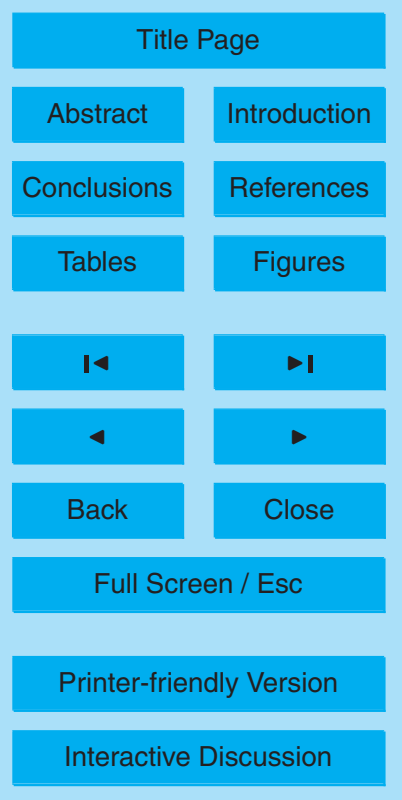


sions, W. R., Diskin, G., Blake, D. R., Wisthaler, A., and Koike, M.: Seasonal variation of the transport of black carbon aerosol from the Asian continent to the Arctic during the ARCTAS aircraft campaign., J. Geophys. Res., in press, 2011. 5948, 5949, 5958

Moteki, N. and Kondo, Y., Dependence of laser-induced incandescence on physical proper5 ties of black carbon aerosols: Measurements and theoretical interpretation, Aerosol Sci. Technol., 44, 663-675, 2010. 5942

Pan, L. L., Bowman, K. P., Atlas, E. L., Wofsy, S. C., Zhang, F., Bresch, J. F., Ridley, B. A., Pittman, J. V., Homeyer, C. R., Romashkin, P., and Cooper, W. A.: The Stratosphere Troposphere Analyses of Regional Transport 2008 experiment, Bull. Am. Meteorol. Soc., 91, 327-342, 2010. 5939, 5942

Panchenko, M. V., Kozlov, V. S., Terpugova, S. A., Shmargunov, V. P., and Burkov, V. V.: Simultaneous measurements of submicron aerosol and absorbing substance in the height range up to $7 \mathrm{~km}$, In Tenth ARM Science Team Meeting Proceeding, San Antonio, Texas, USA, 2000. 5943

Paris, J.-D., Ciais, P., Nédélec, P., Ramonet, M., Belan, B. D., Yu. Arshinov, M., Golitsyn, G. S., Granberg, I., Stohl, A., Cayez, G., Athier, G., Boumard, F., and Cousin, J.-M.: The YAKAEROSIB transcontinental aircraft campaigns: new insights on the transport of $\mathrm{CO}_{2}, \mathrm{CO}$ and $\mathrm{O}_{3}$ across Siberia, Tellus B, 60(4), 551-568, 2008. 5941, 5949

Paris, J.-D., Stohl, A., Ndlec, P., Arshinov, M. Yu., Panchenko, M. V., Shmargunov, V. P., Law, K. S., Belan, B. D., and Ciais, P.: Wildfire smoke in the Siberian Arctic in summer: source characterization and plume evolution from airborne measurements, Atmos. Chem. Phys., 9 , 9315-9327, doi:10.5194/acp-9-9315-2009, 2009. 5939, 5941, 5943

Pfister, G., Hess, P. G., Emmons, L. K., Lamarque, J.-F., Wiedinmyer, C., Edwards, D. P., Petron, G., Gille, J. C., and Sachse, G. W., Quantifying CO emissions from the 2004 alaskan wildfires using MOPITT CO data, Geophys. Res. Lett., 32, L11809, doi:10.1029/2005GL022995, 2005. 5946

Pfister, G. G., Avise, J., Wiedinmyer, C., Edwards, D. P., Emmons, L. K., Diskin, G. D., Podolske, J., and Wisthaler, A.: CO source contribution analysis for California during ARCTAS-CARB, Atmos. Chem. Phys. Discuss., 11, 3627-3661, doi:10.5194/acpd-11-3627-2011, 2011. 5940 so Pisso, I., Real, E., Law, K. S., Legras, B., Bousserez, N., Attie, J. L., and Schlager, $\mathrm{H}$., Estimation of mixing in the troposphere from Lagrangian trace gas reconstructions during long-range pollution plume transport, J. Geophys. Res., 114, D19301, doi:10.1029/2008JD011289, 2009. 5957

\section{ACPD}

$11,5935-5983,2011$

\section{Source contributions to NH CO and black \\ carbon during spring and summer 2008}

S. Tilmes et al.

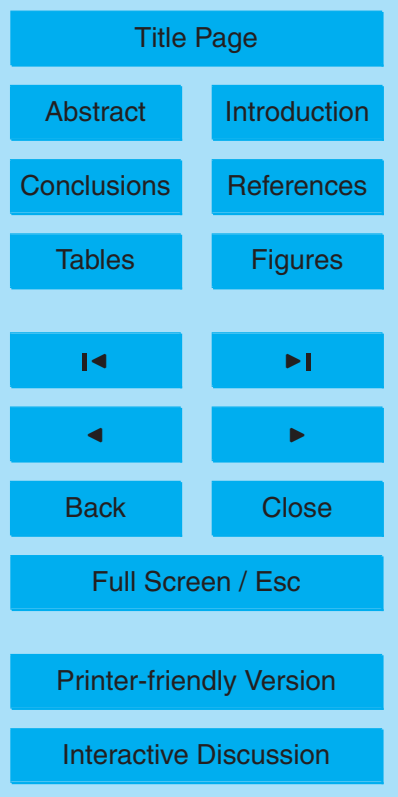


Pommier, M., Law, K. S., Clerbaux, C., Turquety, S., Hurtmans, D., Hadji-Lazaro, J., Coheur, P.F., Schlager, H., Ancellet, G., Paris, J.-D., Ndlec, P., Diskin, G. S., Podolske, J. R., Holloway, J. S., and Bernath, P.: IASI carbon monoxide validation over the Arctic during POLARCAT spring and summer campaigns, Atmos. Chem. Phys., 10, 10655-10678, doi:10.5194/acp10-10655-2010, 2010. 5942

Schwarz, J. P., Spackman, J. R., Gao, R. S., Perring, A. E., Cross, E., Onasch, T. B., Ahern, A., Wrobel, W., Davidovits, P., Olfert, J., Dubey, M. K., Mazzoleni, C., and Fahey, D. W.: The detection efficiency of the single particle soot photometer, Aerosol Sci. Technol., 44(8), 612-628, 2010. 5942

10 Shindell, D. and Faluvegi, G.: Climate response to regional radiative forcing during the twentieth century, Nat. Geosci., 2, 294-300, 2009. 5938

Spackman, J. R., Gao, R. S., Neff, W. D., Schwarz, J. P., Watts, L. A., Fahey, D. W., Holloway, J. S., Ryerson, T. B., Peischl, J., and Brock, C. A.: Aircraft observations of enhancement and depletion of black carbon mass in the springtime Arctic, Atmos. Chem. Phys., 10, 96679680, doi:10.5194/acp-10-9667-2010, 2010. 5942

Tilmes, S., Pan, L., Hoor, P., Sachse, G. W., Loewenstein, M., Lopez, J., Webster, C., Cristensen, L. E., Prott, M., Gao, R.-S., Diskin, G. S., Avery, M. A., Podolske, J. R., Herman, R. L., Spelten, N., Weinheimer, A., Campus, T., Hintsa, E. J., Weinstock, E. M., Pittman, J., Zondl, M. A., Paige, M. E., and Atlas, E.: An aircraft based upper troposphere lower stratosphere $\mathrm{O} 3, \mathrm{CO}$ and $\mathrm{H}_{2} \mathrm{O}$ climatology for the northern hemisphere, J. Geophys. Res., 115, D14303, doi:10.1029/2009JD012731, 2010. 5942

Val Martin, M., Logan, J. A., Kahn, R. A., Leung, F.-Y., Nelson, D. L., and Diner, D. J.: Smoke injection heights from fires in North America: analysis of 5 years of satellite observations, Atmos. Chem. Phys., 10, 1491-1510, doi:10.5194/acp-10-1491-2010, 2010. 5946

van der Werf, G. R., Randerson, J. T., Giglio, L., Gobron, N., and Dolman, A. J.: Climate controls on the variability of fires in the tropics and subtropics, Global Biogeochem. Cy., 22, GB3028, doi:10.1029/2007GB003122, 2008. 5945

Warneke, C., Bahreini, R., Brioude, J., Brock, C. A., De Gouw, J., Fahey, D. W., Froyd, K. D., Holloway, J. S., Middlebrook, A., Miller, L., Montzka, S., Murphy, D. M., Peischl, J., Ryerson, T. B., Schwarz, J. P., Spackman, J. R., and Veres, P.: Biomass burning in Siberia and Kazakhstan as an important source for haze over the Alaskan Arctic in April 2008, Geophys. Res. Lett., 36, L02813, doi:10.1029/2008GL036194, 2009. 5939, 5941, 5947

Wiedinmyer, C., Quayle, B., Geron, C., Belote, A., McKenzie, D., Zhang, X., ONeill, S., and ACPD

Source contributions to NH CO and black carbon during spring and summer 2008

S. Tilmes et al.




Wynne, K. K.: Estimating emissions from fires in North America for air quality modeling, Atmos. Environ., 40, 3419-3432, 2006. 5945

Wiedinmyer, C., Akagi, S. K., Yokelson, R. J., Emmons, L. K., Al-Saadi, J. A., Orlando, J. J., and Soja, A. J.: The Fire INventory from NCAR (FINN) - a high resolution global model to estimate the emissions from open burning, Geosci. Model Dev. Discuss., 3, 2439-2476, doi:10.5194/gmdd-3-2439-2010, 2010. 5945

Zhang, Q., Streets, D. G., Carmichael, G. R., He, K. B., Huo, H., Kannari, A., Klimont, Z., Park, I. S., Reddy, S., Fu, J. S., Chen, D., Duan, L., Lei, Y., Wang, L. T., and Yao, Z. L.: Asian emissions in 2006 for the NASA INTEX-B mission, Atmos. Chem. Phys., 9, 5131-5153, doi:10.5194/acp-9-5131-2009, 2009. 5945

\section{ACPD}

$11,5935-5983,2011$

\section{Source contributions to NH CO and black carbon during spring and summer 2008}

S. Tilmes et al.

Title Page



Introduction

Conclusions

References

Tables

Figures

14
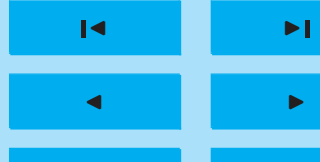

Back

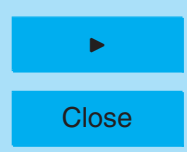

Full Screen / Esc

Printer-friendly Version

Interactive Discussion 


\section{ACPD}

$11,5935-5983,2011$

\section{Source contributions to NH CO and black \\ carbon during spring and summer 2008}

Table 1. Aircraft data used for the three time periods and their geographical coverage.

\begin{tabular}{llccl}
\hline Group & Dates & Latitude $(\mathrm{N})$ & Longitude $(\mathrm{W})$ & Campaign \\
\hline Spring 1 & 4-9 April & $60-88$ & $194-323$ & ARCTAS-A \\
& 30 March-11 April & $68-73$ & $12-25$ & POLARCAT-France \\
Spring 2 & 12-17 April & $58-88$ & $191-218$ & ARCTAS-A \\
& 11-21 April & $63-75$ & $195-234$ & ARCPAC \\
& 18 April-15 May & $26-63$ & $243-274$ & START08/PreHIPPO \\
Summer & 18-24 June & $33-41$ & $233-245$ & ARCTAS-CARB \\
& 16-27 June & $26-63$ & $243-274$ & START08/PreHIPPO \\
& 26 June, 10-13 July & $33-77$ & $238-291$ & ARCTAS-B mid-lat \\
& 1-9 July & $50-87$ & $228-322$ & ARCTAS-B high-lat \\
& 30 June-18 July & $50-81$ & $295-16$ & POLARCAT-GRACE \\
& 30 June-14 July & $59-72$ & $299-315$ & POLARCAT-France \\
& 7-29 July & $51-72$ & $66-171$ & YAK-AEROSIB \\
\hline
\end{tabular}

S. Tilmes et al.

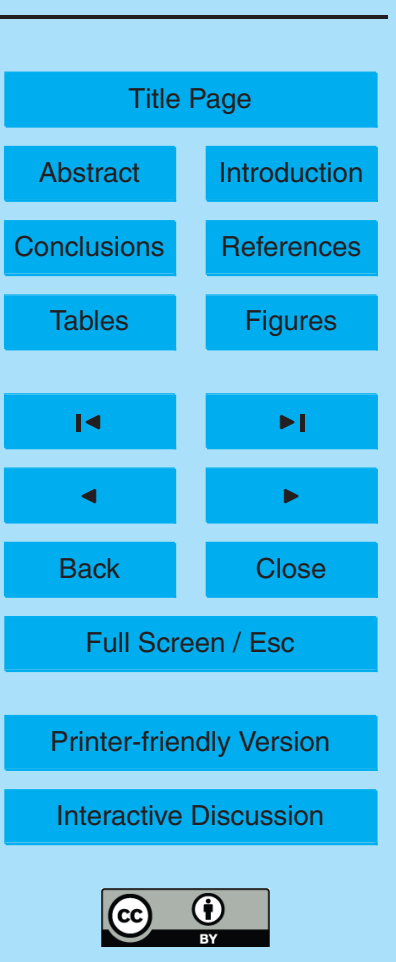


Table 2. Global CO emissions ( $\mathrm{Tg} / \mathrm{month}$ ) of anthropogenic and biomass burning (BB) sources as used by the MOZART-4 model.

\begin{tabular}{lrrr}
\hline Source & Anthr. & BB April & BB July \\
\hline Total & 48.7 & 50.6 & 28.9 \\
Alaska/Canada & 0.3 & 0.04 & 1.2 \\
US & 6.7 & 0.62 & 1.2 \\
Central/America & 1.6 & 3.7 & 0.1 \\
Europe & 6.4 & 1.5 & 1.3 \\
North Africa & 4.8 & 2.3 & 0.1 \\
West-Siberia & 0.3 & 4.0 & 0.2 \\
East-Siberia & 0.5 & 7.8 & 4.4 \\
India & 6.6 & 10.3 & 0.1 \\
China, Korea, Japan & 14.5 & 12.9 & 0.4 \\
SEAsia & 2.6 & 5.7 & 0.5 \\
Southern Hemisphere & 5.0 & 1.9 & 19.5 \\
\hline
\end{tabular}

\section{ACPD}

11, 5935-5983, 2011

\section{Source contributions} to NH CO and black carbon during spring and summer 2008

S. Tilmes et al.

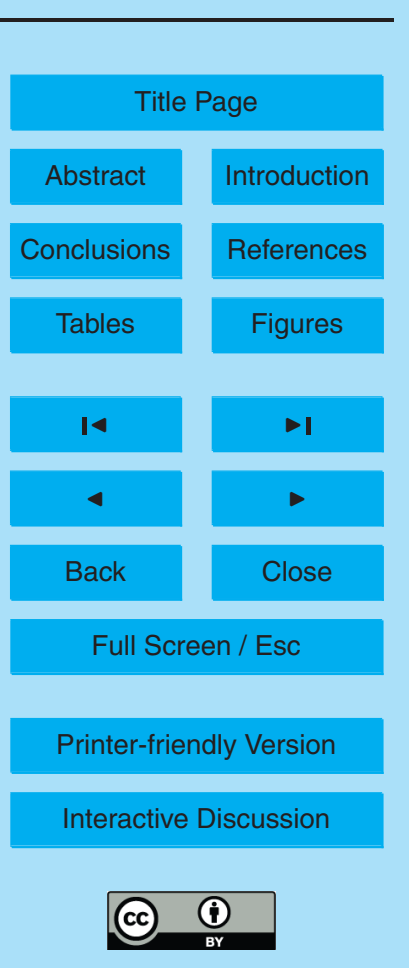




\section{ACPD}

$11,5935-5983,2011$

Source contributions to NH CO and black

carbon during spring and summer 2008

S. Tilmes et al.

Table 3. CO photochemical lifetime (days) derived by the MOZART-4 model.

\begin{tabular}{rrrrrrr}
\hline Latitude & January & February & March & April & May & June \\
\hline $0-30$ & 55 & 49 & 43 & 39 & 36 & 35 \\
$30-60$ & 270 & 183 & 105 & 64 & 44 & 36 \\
$60-90$ & 14176 & 3362 & 778 & 224 & 78 & 52 \\
\hline
\end{tabular}

Title Page

Abstract

Conclusions

Tables

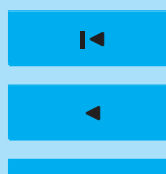

Back

Full Screen / Esc

Printer-friendly Version

Interactive Discussion 

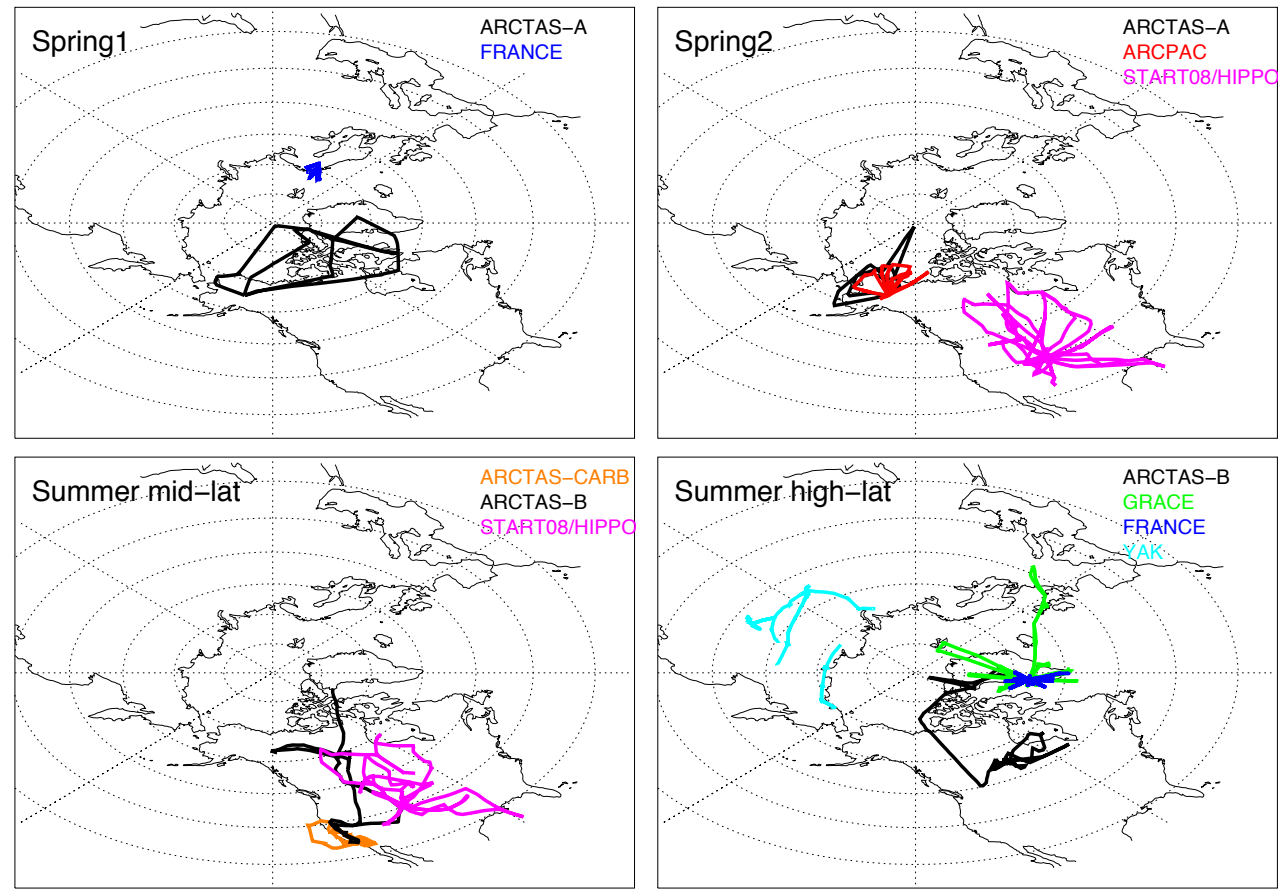

Fig. 1. Spacial coverage of the aircraft observations included in this study between April and July 2008. Aircraft data grouped with regard to mission, location and timing (as described in Table 1) are shown in different colors.

\section{ACPD}

$11,5935-5983,2011$

\section{Source contributions to NH CO and black carbon during spring and summer 2008}

S. Tilmes et al.

Title Page

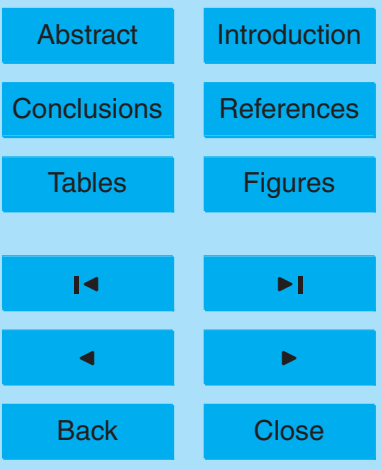

Full Screen / Esc

Printer-friendly Version

Interactive Discussion 


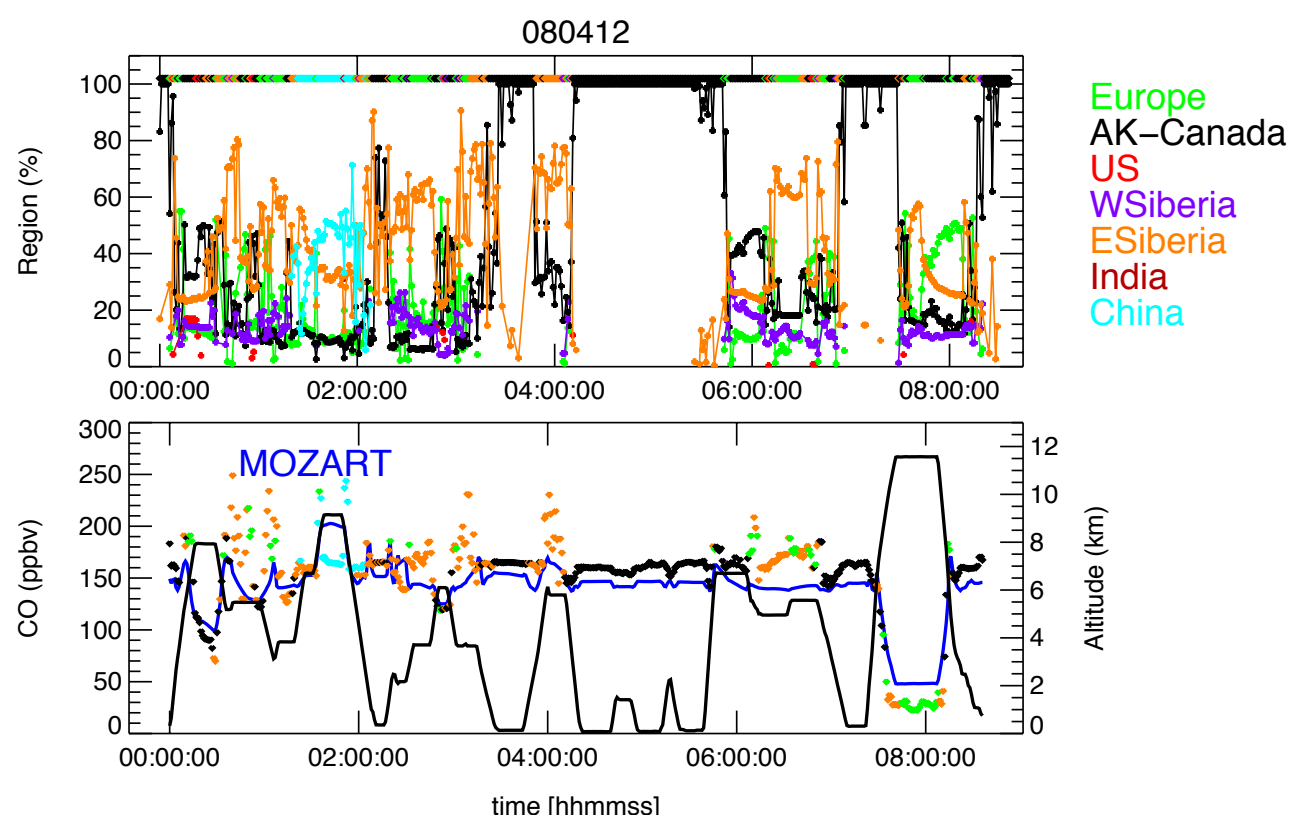

Fig. 2. Top panel: Regional contribution of 10-day backward trajectories that traveled over various regions (as identified in the legend) from each 1-min time sample on the 12 April DC-8 flight (colored lines). Trajectories are followed until they reach an altitude of $2 \mathrm{~km}$ above the ground. Those trajectories that start within $2 \mathrm{~km}$ above the surface are followed for up to 5 days. The origin of the trajectories, shown as colored diamonds at the $100 \%$ line, is defined as the region where trajectories drop below $2 \mathrm{~km}$ or the location after 10 days. Bottom panel: CO measurements on 12 April 2008 are colored based on the region where the 10-day backward trajectory remained the longest time (shown as the largest fraction in the top panel). Altitude of observations is shown in black and corresponding MOZART-4 model results are shown in blue.
ACPD

$11,5935-5983,2011$

\section{Source contributions to NH CO and black carbon during spring and summer 2008}

S. Tilmes et al.

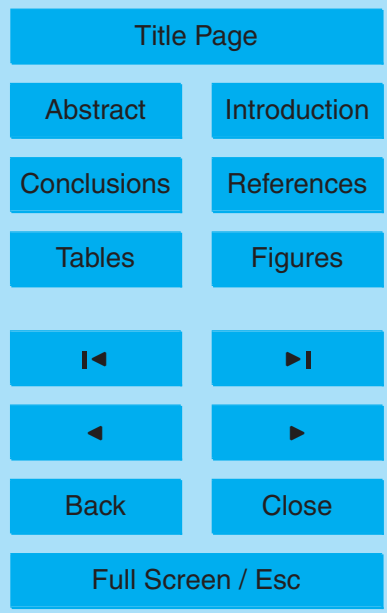

Printer-friendly Version

Interactive Discussion 


\section{ACPD}

$11,5935-5983,2011$

ARCTAS Tag Regions

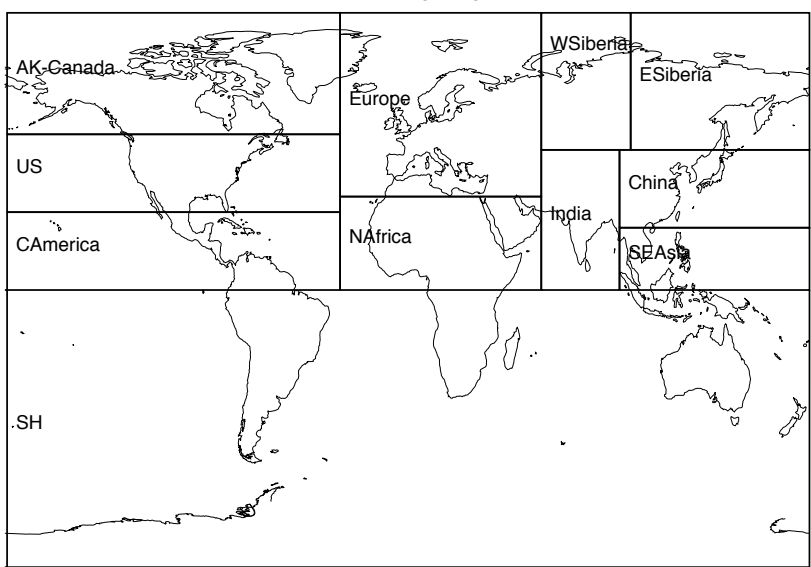

Fig. 3. Definition of regions tagged in the MOZART-4 model: Alaska/Canada (AK-Canada); US (US); Central America (CAmerica); Europe; North Africa (NAfrica); West Siberia (WSiberia); East Siberia (ESiberia); China, Japan and Korea (China); South East Asia (SEAsia); Southern Hemisphere (SH). Two new $\mathrm{CO}$ and black carbon tracers are implemented in the model for each of the different regions, which are only influenced by fire or anthropogenic emissions, respectively.

\section{Source contributions to NH CO and black carbon during spring and summer 2008}

S. Tilmes et al.

\section{Title Page}

\section{Abstract}

Introduction

Conclusions

References

Tables

Figures

14

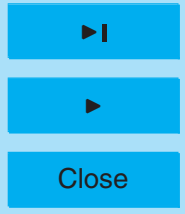

Back

Full Screen / Esc

Printer-friendly Version

Interactive Discussion 
Fire Emissions (no SAsia/SH) 20080408

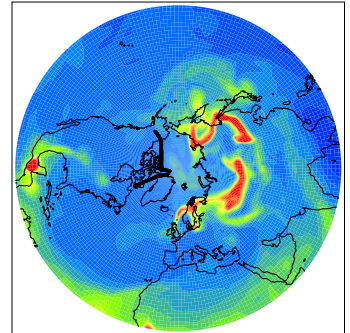

Fire Emissions (no SAsia/SH) 20080416

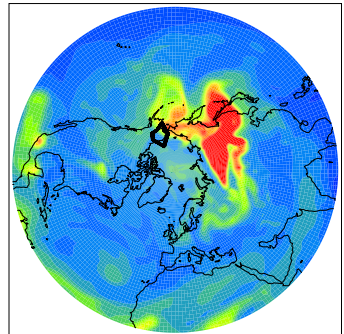

Fire Emissions SAsia/SH 20080408

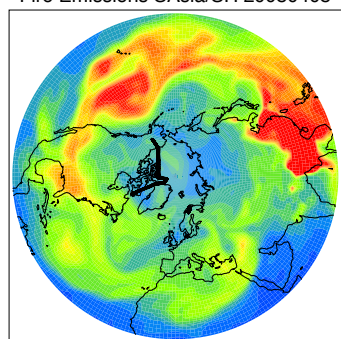

Fire Emissions SAsia/SH 20080416

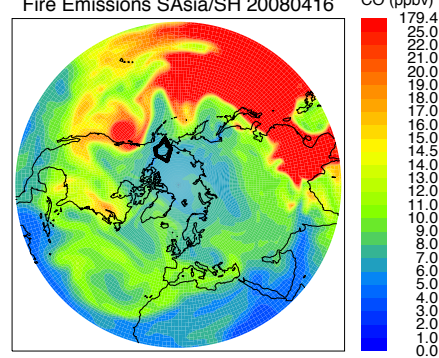

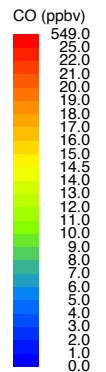

(ppbv)

Fig. 4. CO total column average mixing ratio between surface and $200 \mathrm{hPa}$ are shown for combined CO fire tags for AK-Canada, US, CAmerica, Europe, NAfrica, WSiberia, and ESiberia, as shown in Fig. 3 (left column) and for South Asia (SAsia) - defined here as SEAsia, India, and China - and SH (right column); 8 April (top) and 16 April (bottom). Black lines indicate the flight tracks of the ARCTAS flights for the dates shown.

\section{ACPD}

$11,5935-5983,2011$

\section{Source contributions to NH CO and black \\ carbon during spring and summer 2008}

S. Tilmes et al.

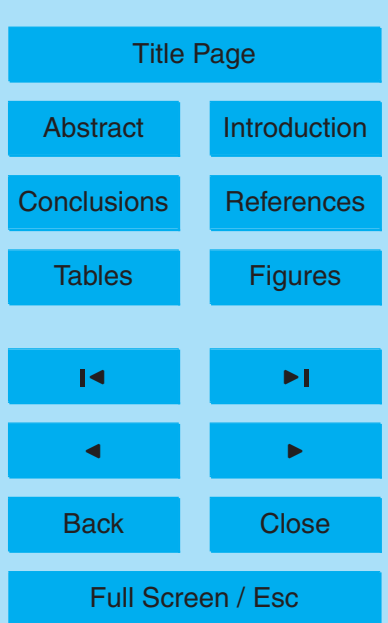

Printer-friendly Version

Interactive Discussion 

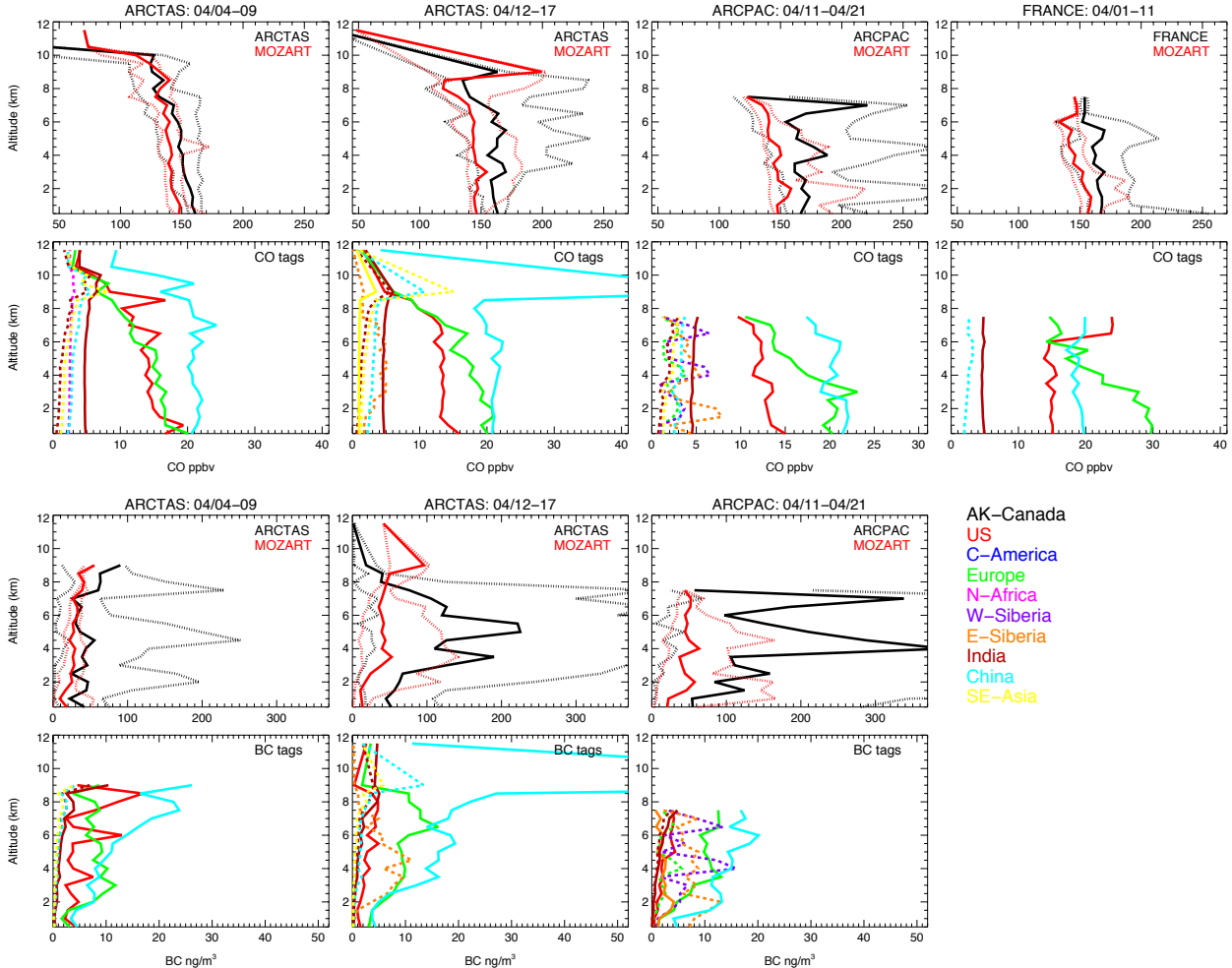

Fig. 5. First row: comparison of the median (solid) and 5 and 95 percentile (dotted) of CO aircraft data and MOZART-4 model results for different periods (as shown on top of each column). Model results are interpolated to the flight track of each flight considered. Second row: $\mathrm{CO}$ tag simulated by the MOZART-4 model, for different source regions, as shown in different colors (see legend on the on the right). Fire tags are shown as dashed lines, anthropogenic tags are shown as solid lines. Third row: same as first row, but for black carbon instead of $\mathrm{CO}$, if observed. Fourth row: same as first row, but for black carbon instead of $\mathrm{CO}$, if observed.
ACPD

11, 5935-5983, 2011

Source contributions to NH CO and black

carbon during spring and summer 2008

S. Tilmes et al.

\section{Title Page}

\section{Abstract}

Introduction

Conclusions

References

Tables

Figures

14

$>1$

4

Back

Close

\section{Full Screen / Esc}

Printer-friendly Version

Interactive Discussion 


\section{ACPD}

$11,5935-5983,2011$
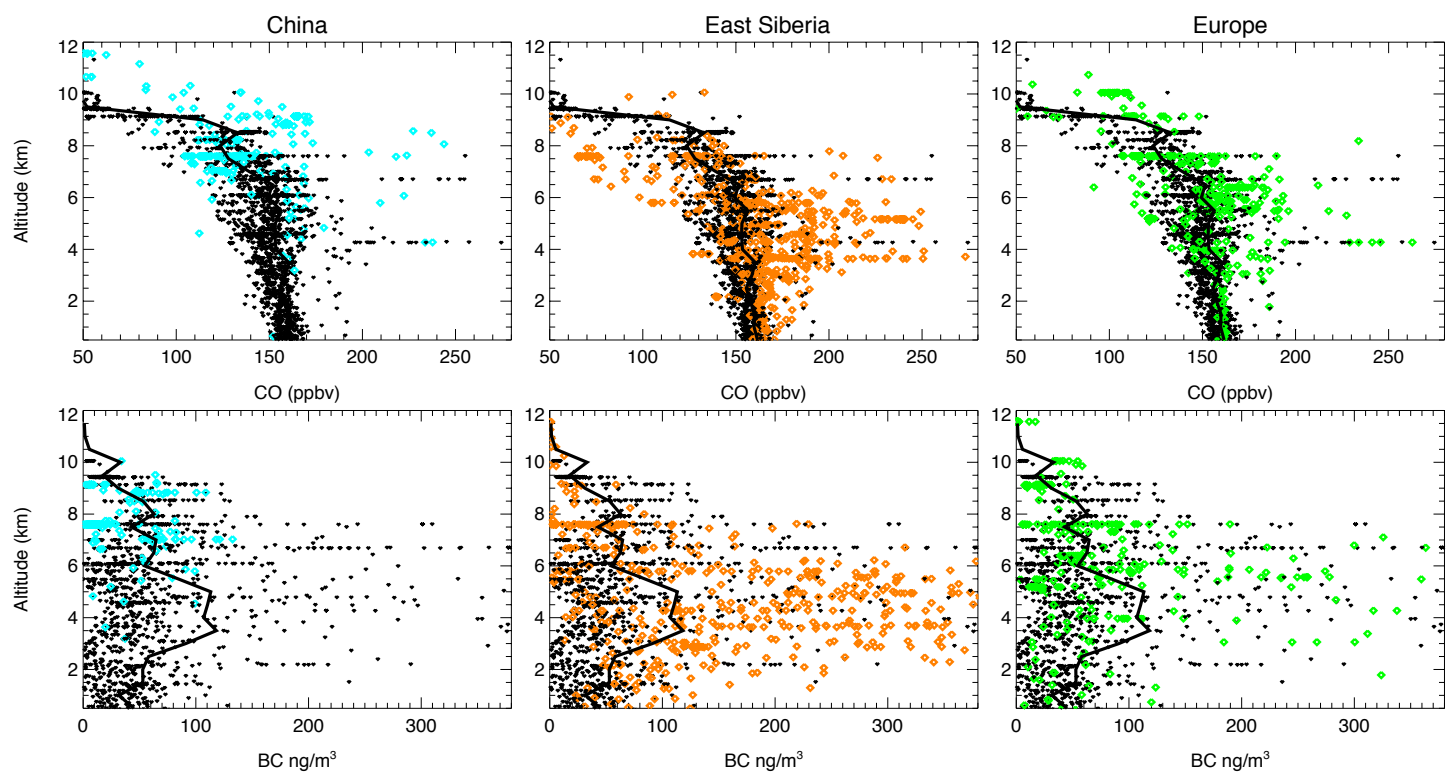

Fig. 6. $C O$ and $B C$ ARCTAS-A airmasses aircraft observations in spring. Colored data points are identified to have their source region in China (left), East-Siberian (middle) and Europe (right) as derived using FLEXPART trajectories. Black data have their origin in Alaska and Canada. Different colors denote a different source region: China (cyan), East-Siberia (orange) and Europe (green). The median of all observations is shown as black solid lines.

Source contributions to NH CO and black carbon during spring and summer 2008

S. Tilmes et al.

Title Page

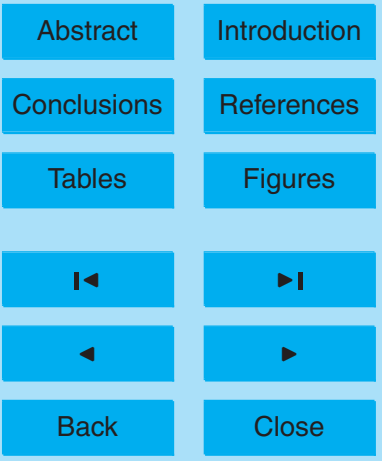

Full Screen / Esc

Printer-friendly Version

Interactive Discussion 


\section{ACPD}

11, 5935-5983, 2011

MOPITT-V4/L3 400 hPa 20080419_20080428

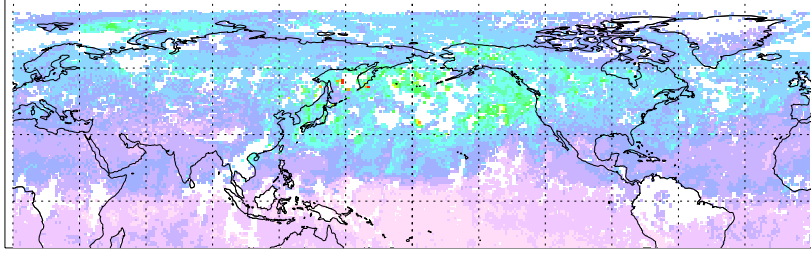

$\begin{array}{llllllllllllll}0 & 40 & 60 & 80 & 100 & 120 & 140 & 160 & 180 & 200 & 220 & 240 & 260 & \text { ppbv }\end{array}$

MOZART`AvgKer minus MOPITT - 2008041920080428 - $400 \mathrm{hPa}$

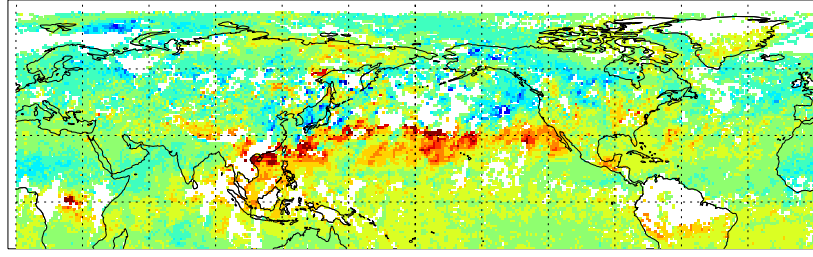

$\begin{array}{llllllllllllll}-90 & -75 & -60 & -45 & -30 & -15 & 0 & 15 & 30 & 45 & 60 & 75 & 90 & \mathrm{ppbv}\end{array}$

Fig. 7. Top panel: CO mixing ratios (ppbv) of MOPITT satellite data at $400 \mathrm{hPa}$ for 19-28 April. Bottom panel: Difference between MOZART-4 CO mixing ratios (ppbv) on the $400 \mathrm{hPa}$ level using the MOPITT averaging kernel and MOPITT data averaged over the same period.

\section{Source contributions to NH CO and black \\ carbon during spring and summer 2008}

S. Tilmes et al.

Title Page

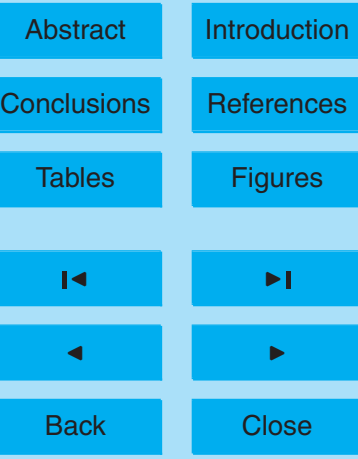

Full Screen / Esc

Printer-friendly Version

Interactive Discussion 

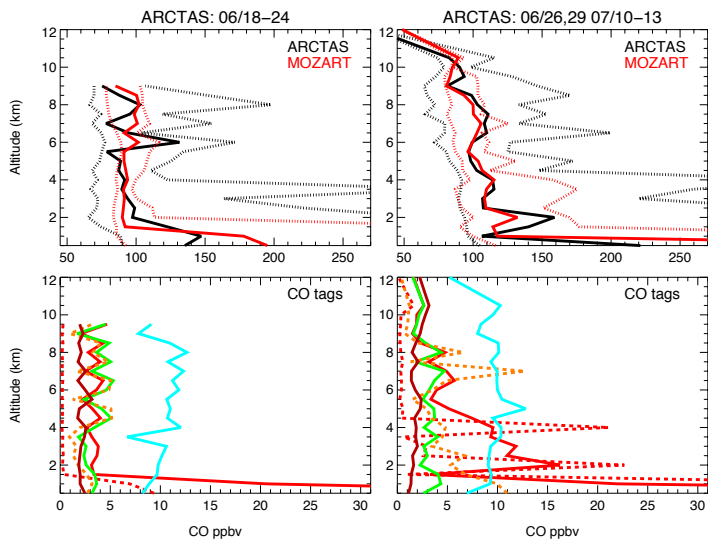

ACPD

11, 5935-5983, 2011

\section{Source contributions} to NH CO and black

carbon during spring and summer 2008

S. Tilmes et al.
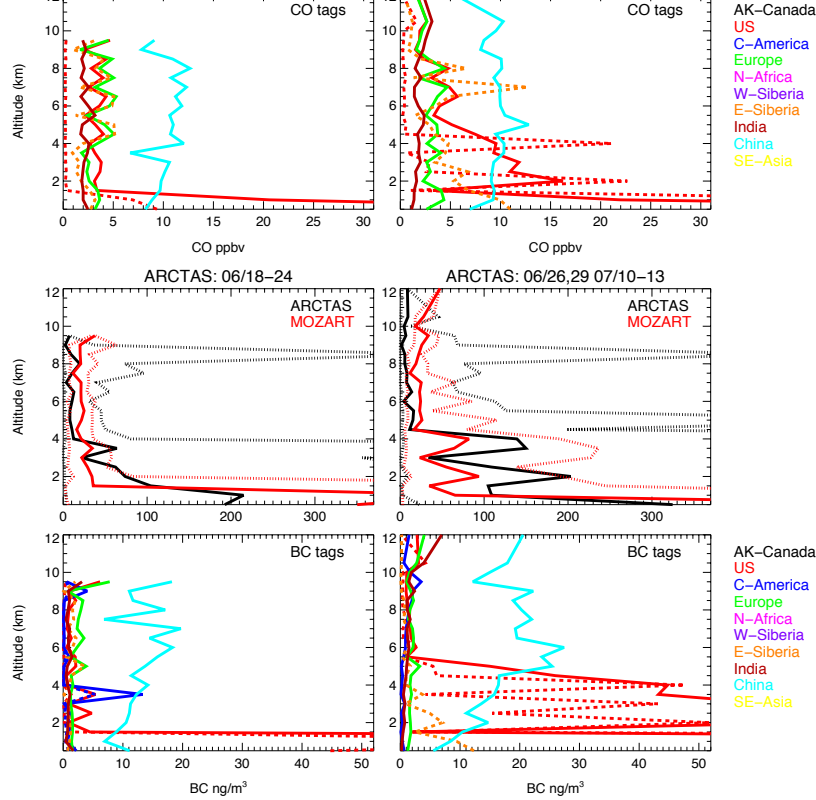

Title Page

Abstract

Introduction

Conclusions

References

Tables

Figures

14

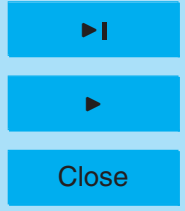

Back

Full Screen / Esc

Fig. 8. Same as Fig. 5, but for periods in summer and mid-latitude coverage.

Printer-friendly Version

Interactive Discussion 

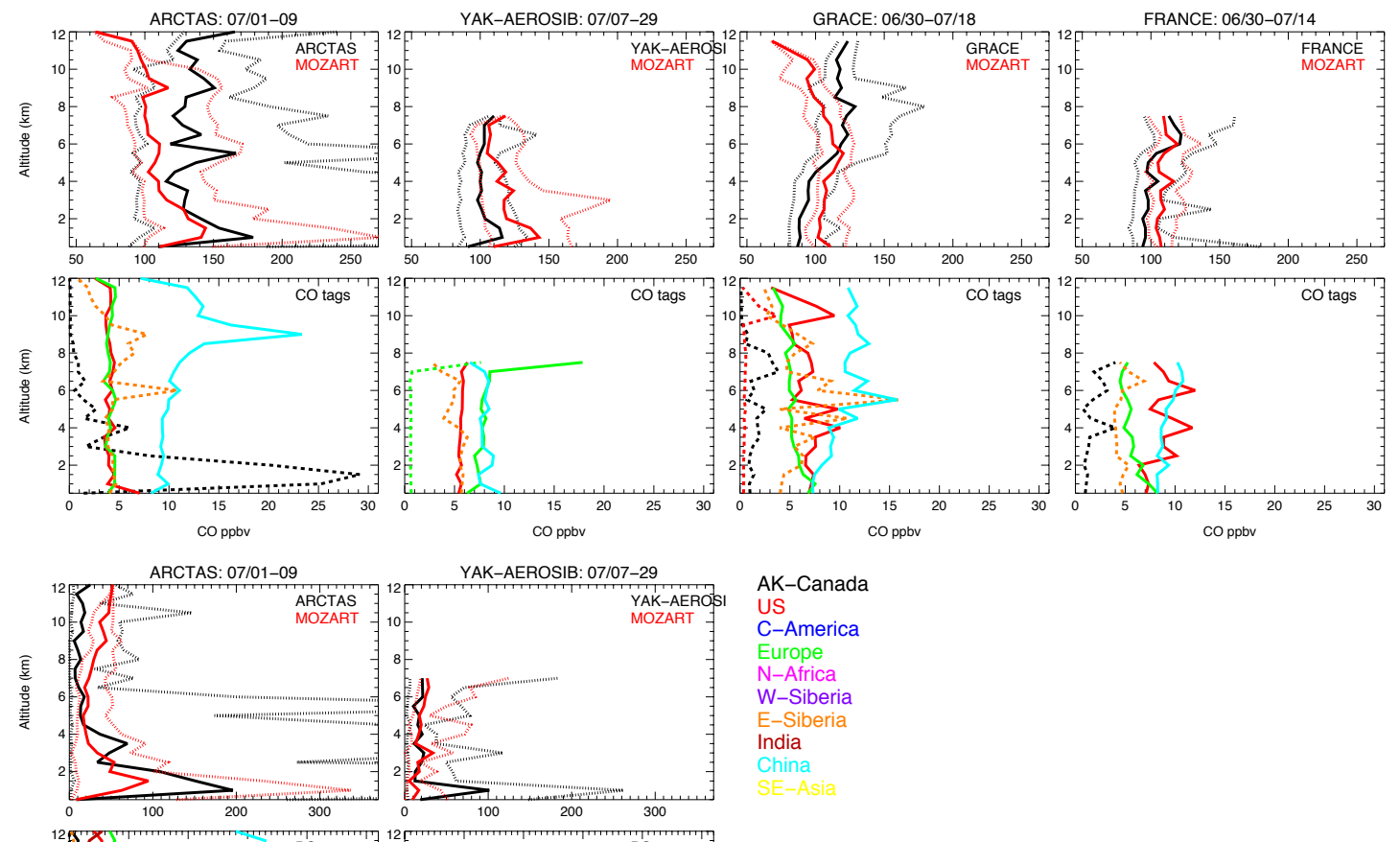

$$
\begin{aligned}
& \text { AK-Canada } \\
& \text { US } \\
& \text { C-America } \\
& \text { Europe } \\
& \text { N-Africa } \\
& \text { W-Siberia } \\
& \text { E-Siberia } \\
& \text { India } \\
& \text { China }
\end{aligned}
$$

CO ppbv

CO ppbv
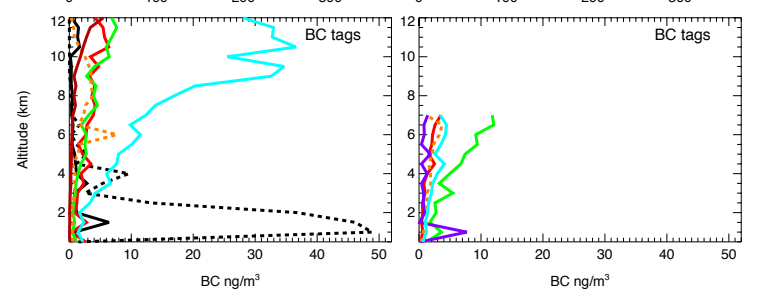

Fig. 9. Same as Fig. 5, but for periods in summer and high-latitude coverage instead.

\section{ACPD}

$11,5935-5983,2011$

Source contributions to NH CO and black carbon during spring and summer 2008

S. Tilmes et al.

Title Page

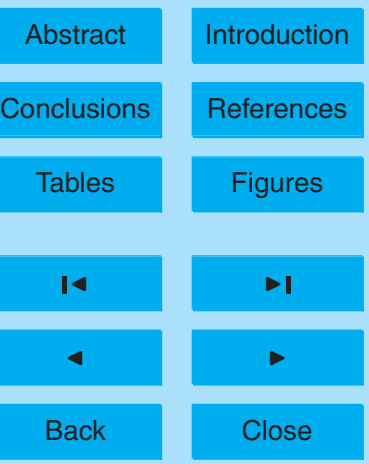

Full Screen / Esc

Printer-friendly Version

Interactive Discussion 


\section{ACPD}

11, 5935-5983, 2011
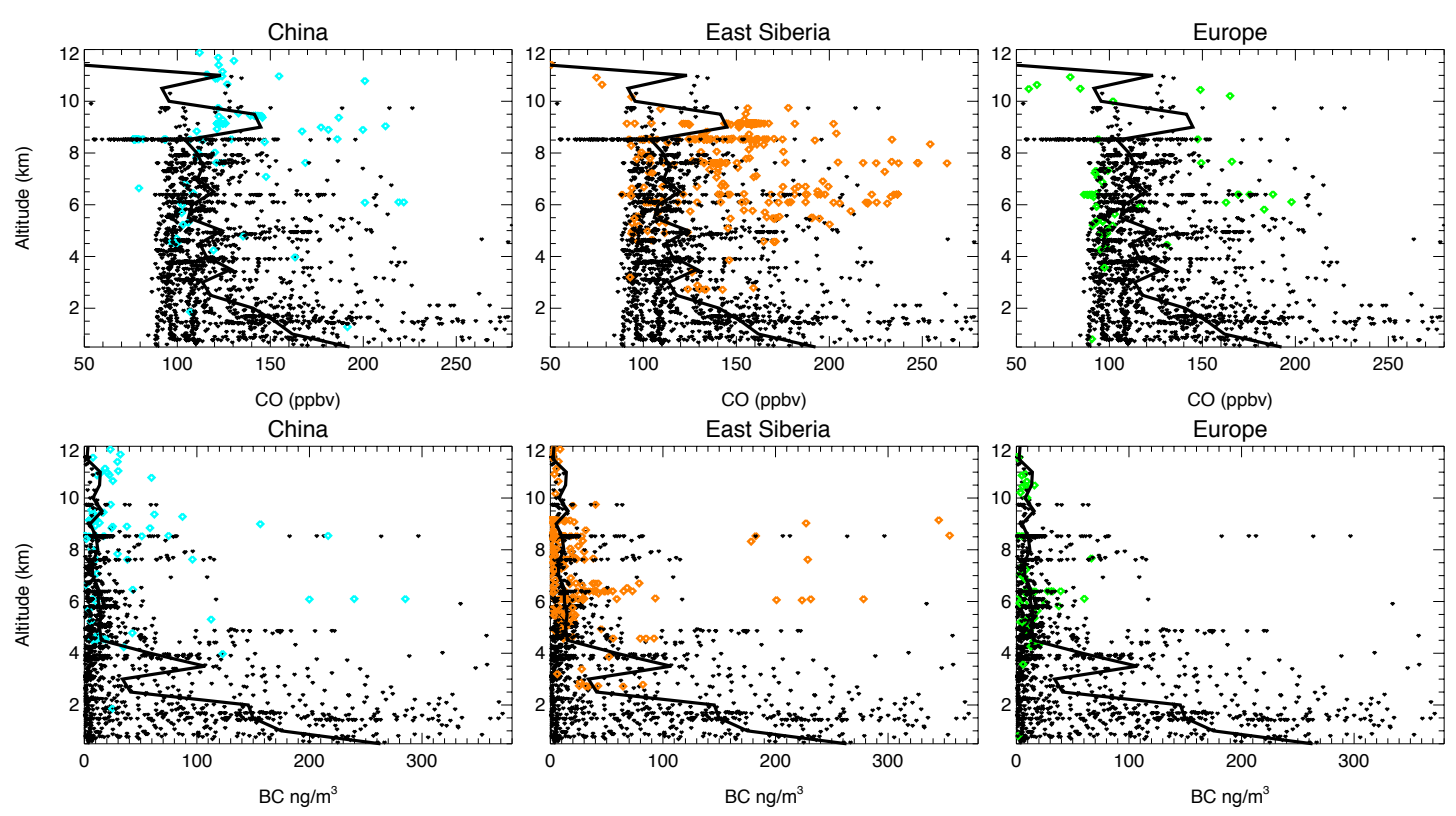

Fig. 10. Same as Fig. 6, but for ARCTAS-B in summer.

\section{Source contributions to NH CO and black carbon during spring and summer 2008}

S. Tilmes et al.

\section{Title Page}

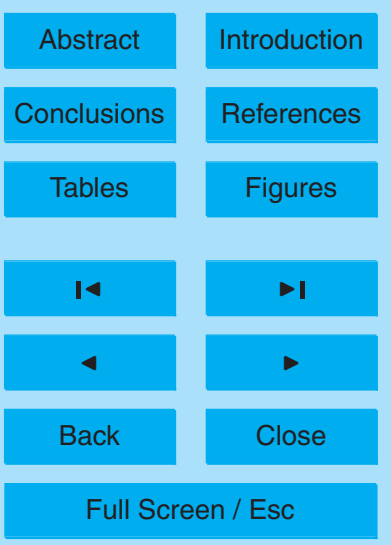

Printer-friendly Version

Interactive Discussion 


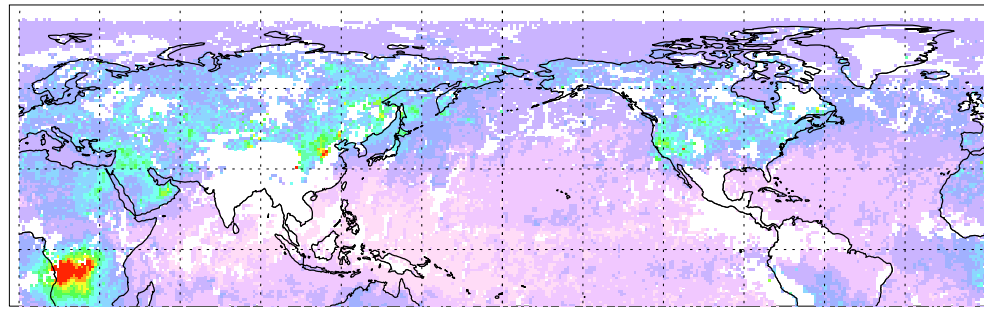

$11,5935-5983,2011$

\section{Source contributions to NH CO and black carbon during spring and summer 2008}

S. Tilmes et al.

$\begin{array}{lllllllllllll}0 & 40 & 60 & 80 & 100 & 120 & 140 & 160 & 180 & 200 & 220 & 240 & 260 \\ \text { ppbv }\end{array}$

MOZART*AvgKer minus MOPITT - 20080701_20080710 - 800 hPa

Title Page

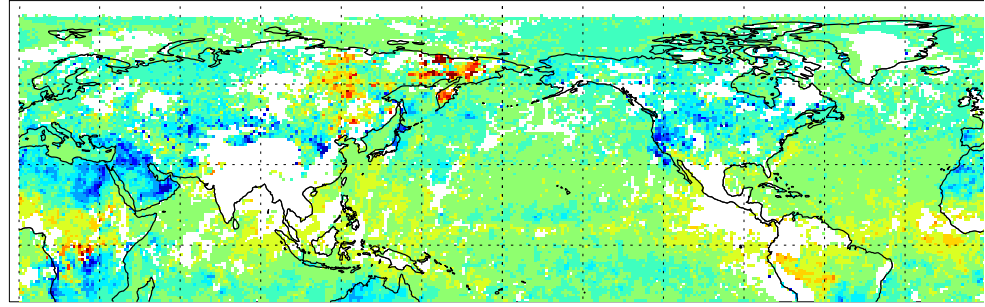

Abstract

Conclusions

Tables

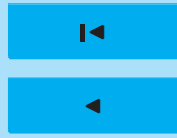

Back

Full Screen / Esc

Fig. 11. Top panel: $C O$ mixing ratios (ppbv) of MOPITT satellite data at $800 \mathrm{hPa}$ for $1-10$ July. Bottom panel: Difference between MOZART-4 CO mixing ratios (ppbv) on the $800 \mathrm{hPa}$ level using the MOPITT averaging kernel and MOPITT data averaged over the same period.
Printer-friendly Version

Interactive Discussion 


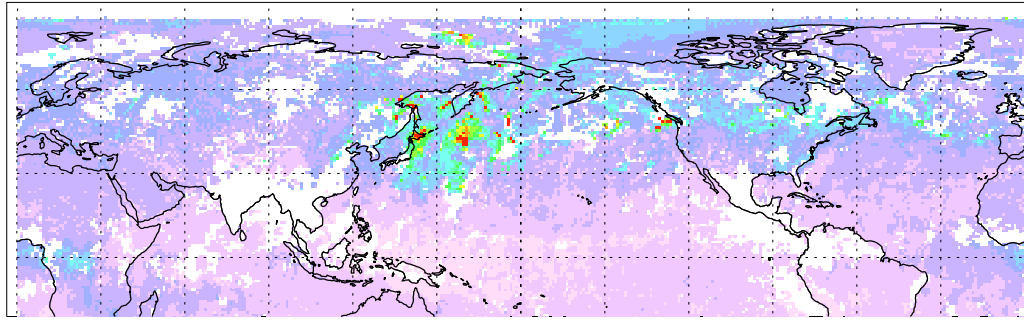

$\begin{array}{lllllllllllll}0 & 40 & 60 & 80 & 100 & 120 & 140 & 160 & 180 & 200 & 220 & 240 & 260 \\ \text { ppbv }\end{array}$ MOZART*AvgKer minus MOPITT - 20080701_20080710 - 400 hPa
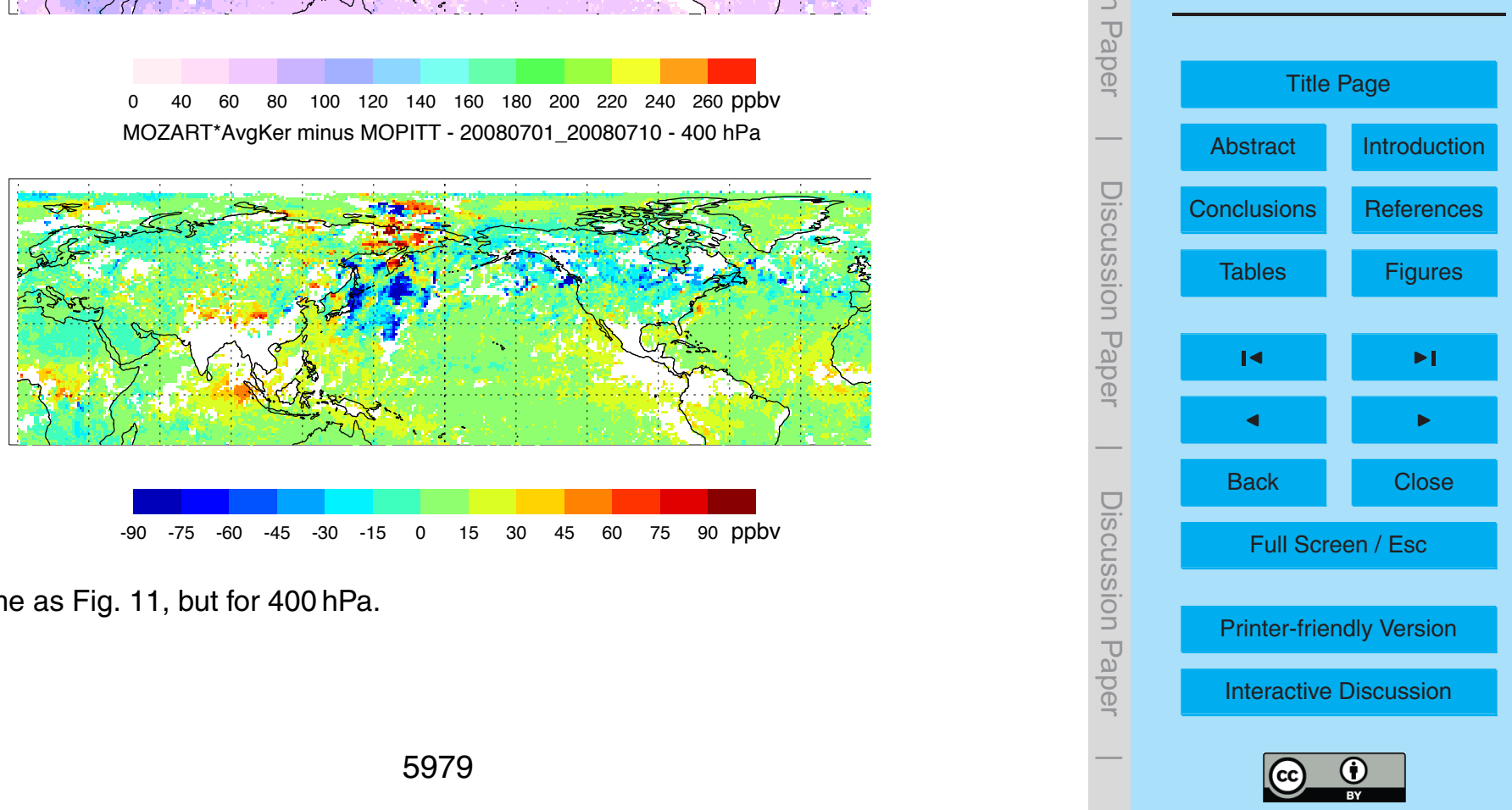

Title Page

\section{Source contributions to NH CO and black carbon during spring and summer 2008}

S. Tilmes et al.

Fig. 12. Same as Fig. 11, but for $400 \mathrm{hPa}$. 

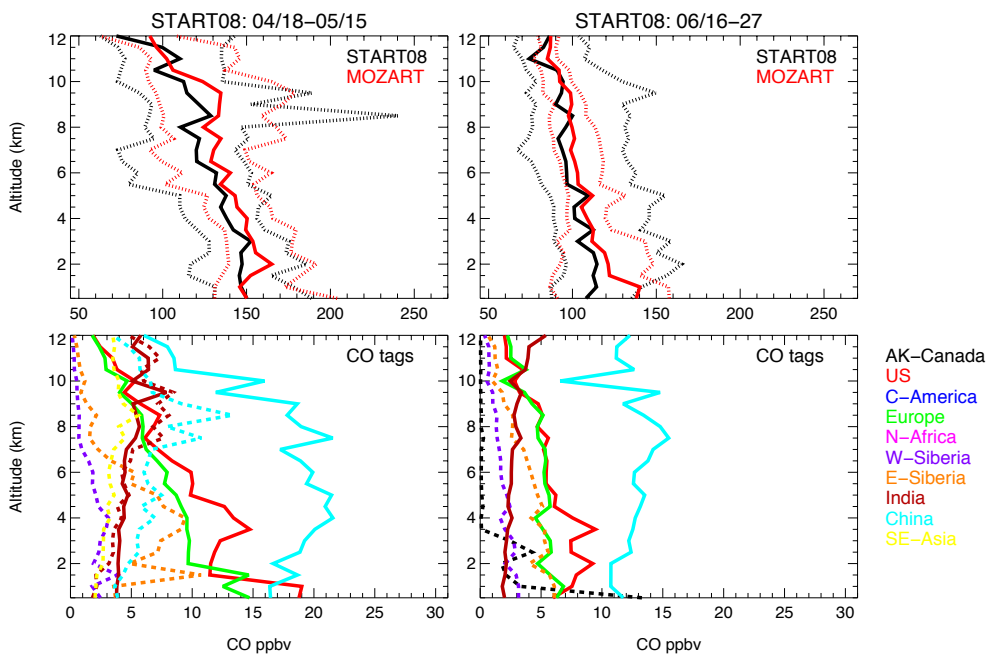

Fig. 13. Same as Fig. 5, but for START08 campaign between April and June.

\section{ACPD}

11, 5935-5983, 2011

\section{Source contributions} to NH CO and black

carbon during spring and summer 2008

S. Tilmes et al.

Title Page

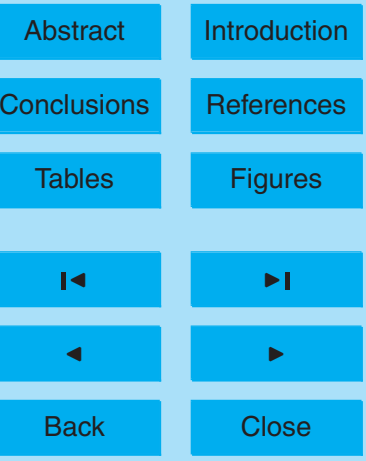

Full Screen / Esc

Printer-friendly Version

Interactive Discussion 
Anthropogenic CO Contributions
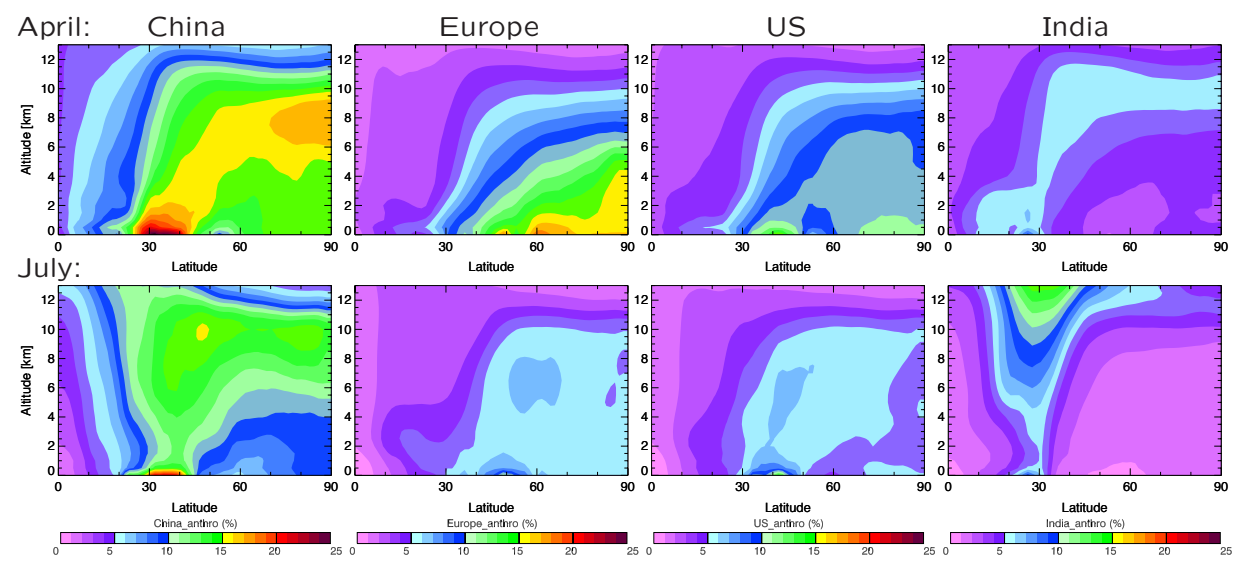

Fire CO Contributions
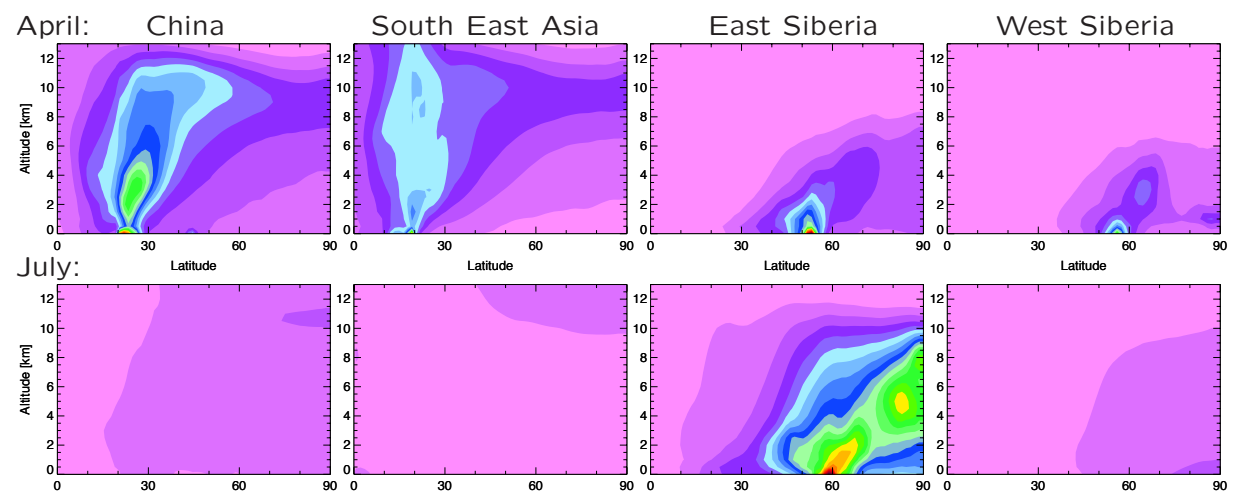

Latitude Latitude
SEAsia_fire $(\%)$
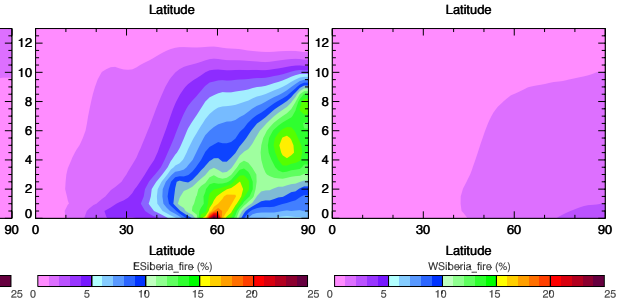

Fig. 14. Zonally averaged vertical distribution of the relative $C O$ anthropogenic and fire contributions for different source regions (see Fig. 3) for the Northern Hemisphere in April and July 2008 calculated by MOZART-4.

\section{ACPD}

$11,5935-5983,2011$

Source contributions to NH CO and black carbon during spring and summer 2008

S. Tilmes et al.

Title Page

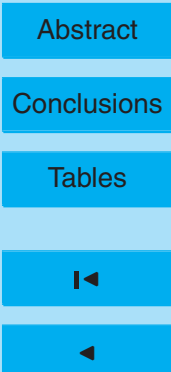

Introduction

References

Figures

$>1$

$>$

Back

Close

\section{Full Screen / Esc}

Printer-friendly Version

Interactive Discussion 
Anthropogenic Black Carbon Contributions

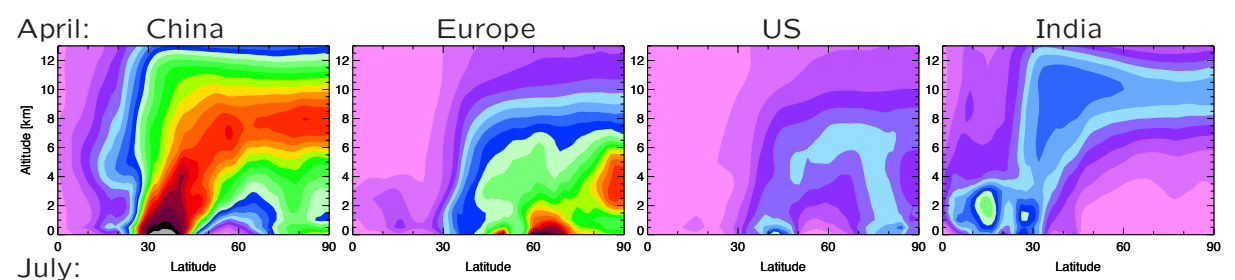

\section{ACPD}

$11,5935-5983,2011$

Source contributions to NH CO and black carbon during spring and summer 2008

S. Tilmes et al.

Title Page

Fire Black Carbon Contributions
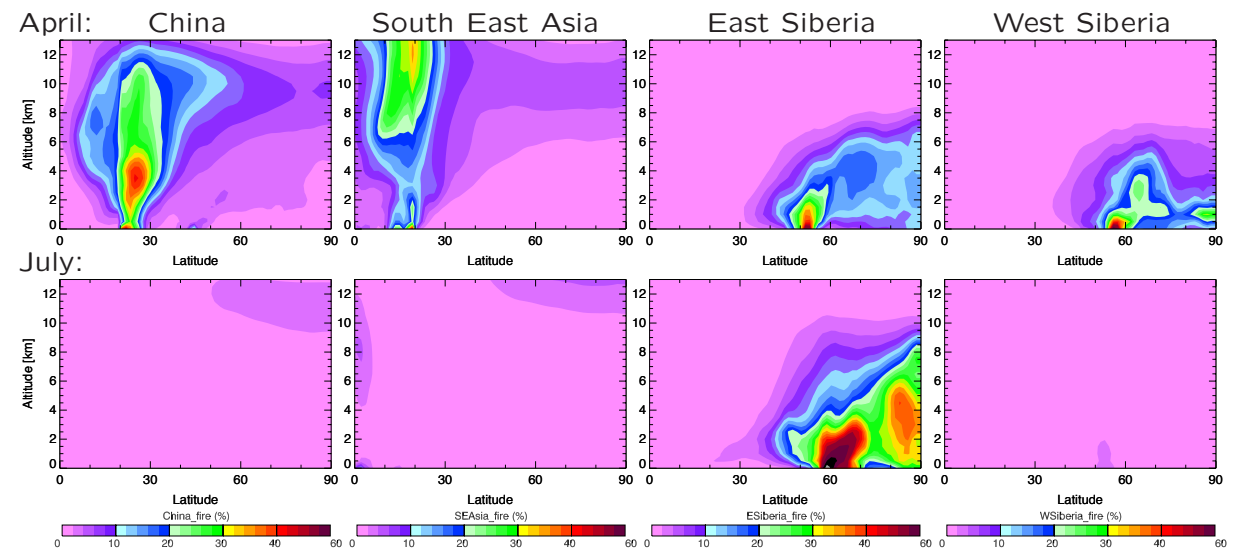

Fig. 15. Zonally averaged vertical distribution of the relative $B C$ anthropogenic and fire contributions for different source regions (see Fig. 3) for the Northern Hemisphere in April and July 2008 calculated by MOZART-4.

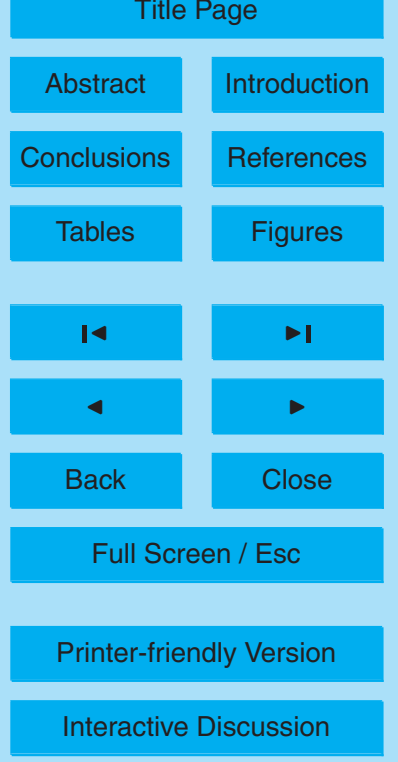

Interactive Discussion

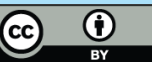



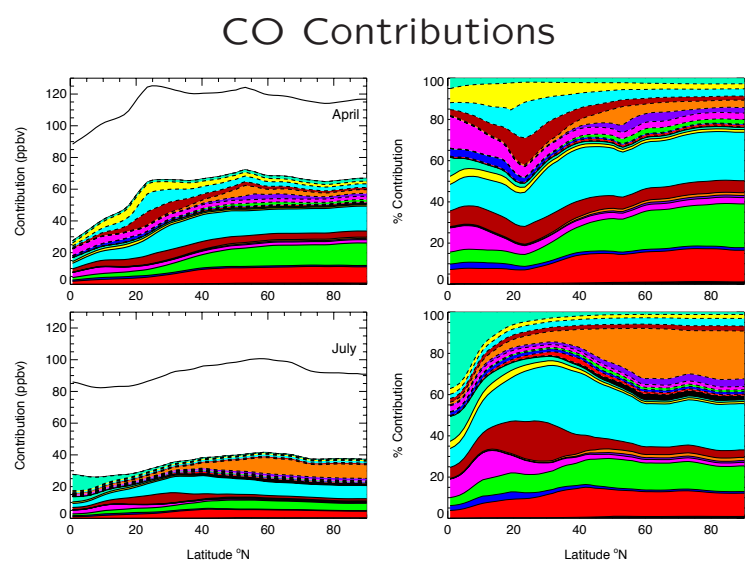

BC Contributions
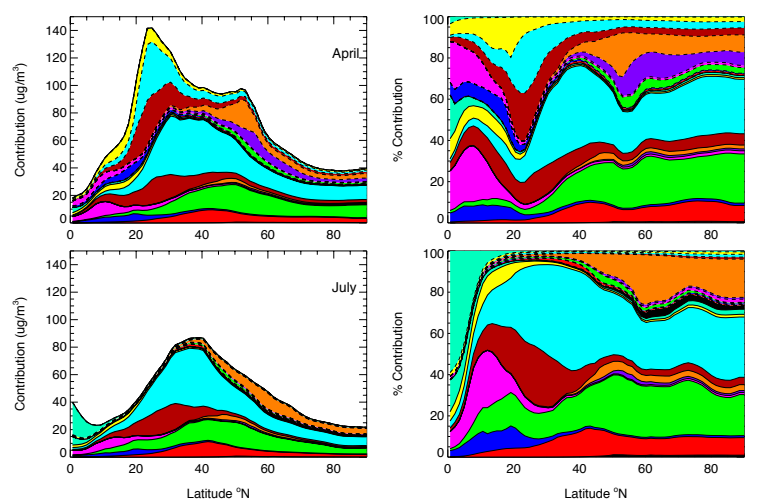

\section{ACPD}

11, 5935-5983, 2011

\section{Source contributions to NH CO and black carbon during spring and summer 2008}

S. Tilmes et al.

\section{Title Page}

\section{Abstract}

\section{Conclusions}

\section{Tables}

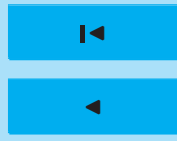

\section{Back}

Full Screen / Esc

Printer-friendly Version

Interactive Discussion
Fig. 16. Absolute (left) and relative (right) $C O$ and $B C$ contributions of zonally averaged column average mixing ratio of defined source regions (see Fig. 3) (different colors) for the Northern Hemisphere in April and July 2008 calculated by MOZART-4. 